\title{
Activating transcription factor 3 and the nervous system
}

\author{
David Hunt ${ }^{1}$, Gennadij Raivich ${ }^{2}$ and Patrick Norval Anderson ${ }^{3}$ * \\ ${ }^{1}$ Medical Education Centre, Newham University Hospital, London, UK \\ ${ }_{2}^{2}$ Perinatal Brain Repair Group, Institute for Women's Health, University College London, London, UK \\ ${ }^{3}$ Research Department of Cell and Developmental Biology, University College London, London, UK
}

\section{Edited by:}

Simone Di Giovanni, University of

Tuebingen, Germany

Reviewed by:

Hiroshi Kiyama, Nagoya University, Japan

Simone Di Giovanni, University of

Tuebingen, Germany

${ }^{*}$ Correspondence:

Patrick Norval Anderson, Department of Cell and Developmental Biology, Anatomy Building, University College London, Gower Street, London WC1E 6BT, UK.

e-mail:p.anderson@ucl.ac.uk
Activating transcription factor 3 (ATF3) belongs to the ATF/cyclic AMP responsive element binding family of transcription factors and is often described as an adaptive response gene whose activity is usually regulated by stressful stimuli. Although expressed in a number of splice variants and generally recognized as a transcriptional repressor, ATF3 has the ability to interact with a number of other transcription factors including c-Jun to form complexes which not only repress, but can also activate various genes. ATF3 expression is modulated mainly at the transcriptional level and has markedly different effects in different types of cell. The levels of ATF3 mRNA and protein are normally very low in neurons and glia but their expression is rapidly upregulated in response to injury. ATF3 expression in neurons is closely linked to their survival and the regeneration of their axons following axotomy, and that in peripheral nerves correlates with the generation of a Schwann cell phenotype that is conducive to axonal regeneration. ATF3 is also induced by Toll-like receptor (TLR) ligands but acts as a negative regulator of TLR signaling, suppressing the innate immune response which is involved in immuno-surveillance and can enhance or reduce the survival of injured neurons and promote the regeneration of their axons.

Keywords: ATF3, c-Jun

\section{INTRODUCTION}

It has long been known that the ability of peripheral axons to regenerate is fundamentally greater than that of axons in the brain, spinal cord, or optic nerves (early literature was reviewed in Ramon y Cajal, 1928). One factor that contributes to the successful regeneration of the axons in peripheral nerves is the complex cell body response the neurons show to axotomy. That transcription factors must play an important role in enabling neurons to regrow their axons is implicit to the observation that several hundred genes are regulated in neurons during axonal regeneration (Costigan et al., 2002; Boeshore et al., 2004). In addition, similarly large numbers of genes are regulated in the non-neuronal cells present in injured peripheral nerves, especially Schwann cells (Barrette et al., 2010). Of the transcription factors that regulate these changes in gene expression, the function of c-Jun is the best understood. However, activating transcription factor 3 (ATF3), also known as LRF-1, LRG-21, CRG-5, and TI-241, is also upregulated in most of the neurons (Figure 1) as well as in Schwann cells that express c-Jun. Indeed, ATF3 has become a standard marker for neurons axotomized by peripheral nerve injury (Tsuzuki et al., 2001; Yamanaka et al., 2005; Yano et al., 2008; Linda et al., 2011) and its expression by injured neurons is closely correlated with a regenerative response. None the less, surprisingly little is known about the functions of ATF3 in neurons or glia within the injured nervous system, especially when compared with those of its potential binding partner, c-Jun.

\section{THE ATF/CREB FAMILY}

Activating transcription factor 3 belongs to the ATF/cyclic AMP responsive element binding (CREB) family of transcription factors, characterized by a basic region leucine zipper (bZip) motif. The basic region is necessary for binding to the ATF/CRE promoter DNA sequence (TGACGTCA), and the leucine zipper element for homo- and hetero-dimerization with other bZip proteins to differentially regulate transcription. Within this relatively large family there are a number of subgroups which have been classified according to their level of homology both within and outside the bZip domain. Between subgroups, however, there is very little similarity outside the bZip domain (Hai and Hartman, 2001). None the less, some ATF/CREB members can form heterodimers with members of other families (e.g., C/EBP and Maf families), as well as with various other ATF/CREB proteins (Thompson et al., 2009).

\section{The ATF3 gene}

Full-length ATF3 was originally isolated from a serum-induced HeLa cell cDNA library using a DNA probe (Hai et al., 1989). The ATF3 gene is on chromosome 1q32.3 and spans $\sim 56 \mathrm{~kb}$, technically comprising six exons (see Figure 2). In vitro experiments suggest that the human ATF3 gene has two promoters, with the most recently identified alternate promoter (labeled P1 in Figure 2) being some $\sim 43.5 \mathrm{~kb}$ upstream from the established canonical promoter (labeled P2 in Figure 2). This novel promoter appears to be highly conserved between human and mouse (Miyazaki et al., 2009). There are al multiple P1 transcription start sites. Using RNAi against $\mathrm{P} 1$ and $\mathrm{P} 2$ transcripts, Miyazaki and colleagues were able to show that $\mathrm{P} 1$ activity was dominant in cancer cells expressing ATF3 in response to serum, whilst P2 activity was dominant in cells expressing oncogenic hRas. This alternate promoter usage is intriguing, not least because the variant transcripts give rise to 

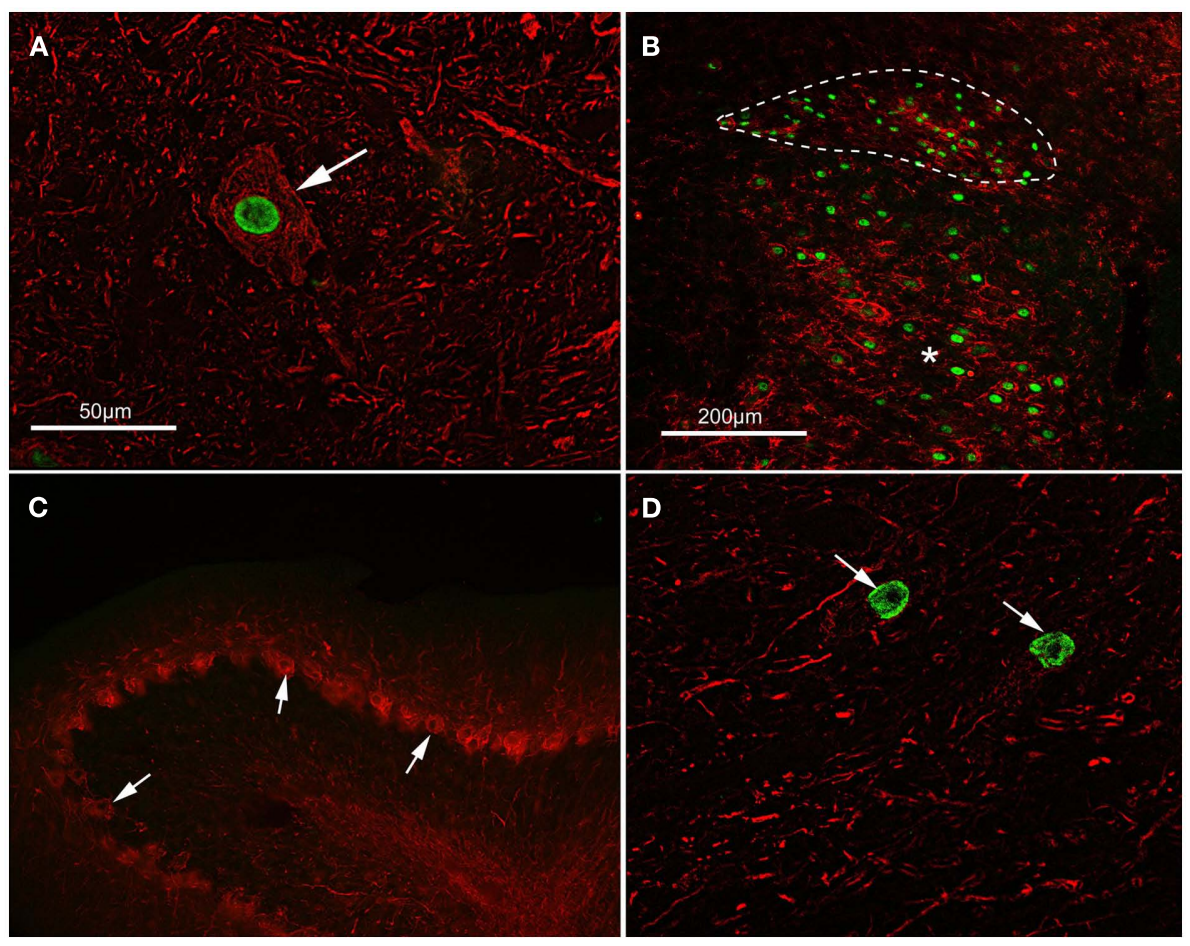

FIGURE 1 | Activating transcription factor 3 (ATF3) is expressed in axotomized, regeneration-competent neurons. (A) ATF3 (green) is concentrated in the nucleus of a lumbar motor neuron (arrowed) from an adult rat 14 days following sciatic nerve transaction. This type of cell regenerates its axon vigorously following nerve injury. Neurofilament immunoreactivity (red) has been used to show neuronal cytoplasm. The scale bar also applies to (D). (B) ATF3 (green) is present in the nuclei of preganglionic parasympathetic neurons in the dorsal nucleus of the vagus (outlined with a dashed line) and in motor neurons of the hypoglossal nucleus (asterisk) 5 days after crush injury to the vagus and hypoglossal nerves in an adult rat. These neurons also regenerate axons following injury. CD11b immunoreactivity (red) shows reactive microglia around the axotomized neurons. The scale bar also applies to (C). (C,D) Show the results of an experiment where a peripheral nerve graft was implanted into the cerebellum of an adult rat, axotomizing both deep nucleus neurons and Purkinje cells. Fourteen days after grafting, ATF3 (green) can be seen in the nuclei (arrows) of neurons within a cerebellar deep nucleus in (D) but not in the nuclei of Purkinje cells, arrowed in (C). Deep nucleus neurons regenerate axons into grafts in the cerebellum but Purkinje cells do not do so; ATF3 is expressed only by the neurons which mount a regenerative response to axotomy. Neurofilament and calbindin immunoreactivity (red) has been used to identify Purkinje cells. the same protein. The variant $5^{\prime}$ UTR sequences may be important in the regulation of translation; Miyazaki et al. (2009) reported that the structure of the $5^{\prime}$ UTRs of the P1 transcripts, as well as the differential use of transcription start sites appears to affect the level of translation in response to stress. There was evidence for the constitutive activation of P1 in two cancer cell lines, LNCaP and Hodgkin L428.

\section{Alternative mRNA splicing and protein isoforms}

Numerous splice variants have been reported which give rise to truncated forms of ATF3 (see Figure 2). The first described variant results in a protein termed ATF3 $\Delta$ zip owing to its loss of the carboxy-terminal leucine zipper dimerization domain (Chen et al., 1994). The resultant protein is truncated at 118 aminoacids (118aa). The expression of two other splice variants of ATF3 was demonstrated by using RT-PCR on cDNA from primary human umbilical vein endothelial cells treated with the calcium ionophore A23187 (Hashimoto et al., 2002). Somewhat surprisingly, although these two variant transcripts were abundant, ATF3 $\Delta$ zip was not detectable in this system. Subsequent analysis of the two novel variant transcripts revealed that they both gave rise to the same protein isoform, truncated at the carboxy terminus and lacking the leucine zipper dimerization domain. The authors have termed the variant transcripts $A T F 3 \Delta z i p 2 a$ and $A T F 3 \Delta z i p 2 b$, and their common 135aa protein ATF3 $\Delta$ zip2 (which shares its first 115aa with full-length ATF3).

Two novel ATF3 mRNA isoforms have been described in human HepG2 hepatoma cells undergoing metabolic stress (Pan et al., 2003); both were detected by RT-PCR. The first- ATF3 3 zip $2 c-$ gives rise to a $106 \mathrm{aa}$ protein and is identical to the ATF3 $\Delta$ zip2 isoform except for a further truncation of 29aa near the $\mathrm{N}$ terminus. The second splice variant, termed ATF3 $\Delta$ zip3, is similar to the ATF3 $\Delta$ zip2b splice variant. However, it retains the sequence between exons $\mathrm{C}$ and $\mathrm{D}^{\prime}$, which the authors term $\mathrm{C}^{\prime}$; this introduces an early in-frame stop codon, giving rise to a 120aa protein truncated at the carboxy terminus. Interestingly, Pan et al. did not detect expression of ATF3 $\Delta$ zip, ATF3 $\Delta$ zip2a, or ATF3 $\Delta$ zip2b in HepG2 cells.

Finally, an ATF3 mRNA splice variant termed ATF3 $b$ has been identified in $\alpha$ TC1.6 cells, which results from splicing of 106 bases within exon B (Wang et al., 2003). An early in-frame stop codon is introduced at the site corresponding to position 10 in the ATF3 
A ATF3 gene ( 56kb, chromosome 1q32.3)

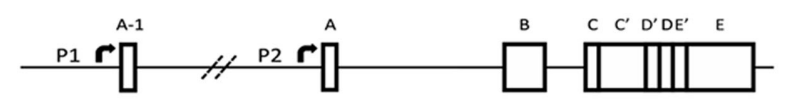

ATF3 Transcripts

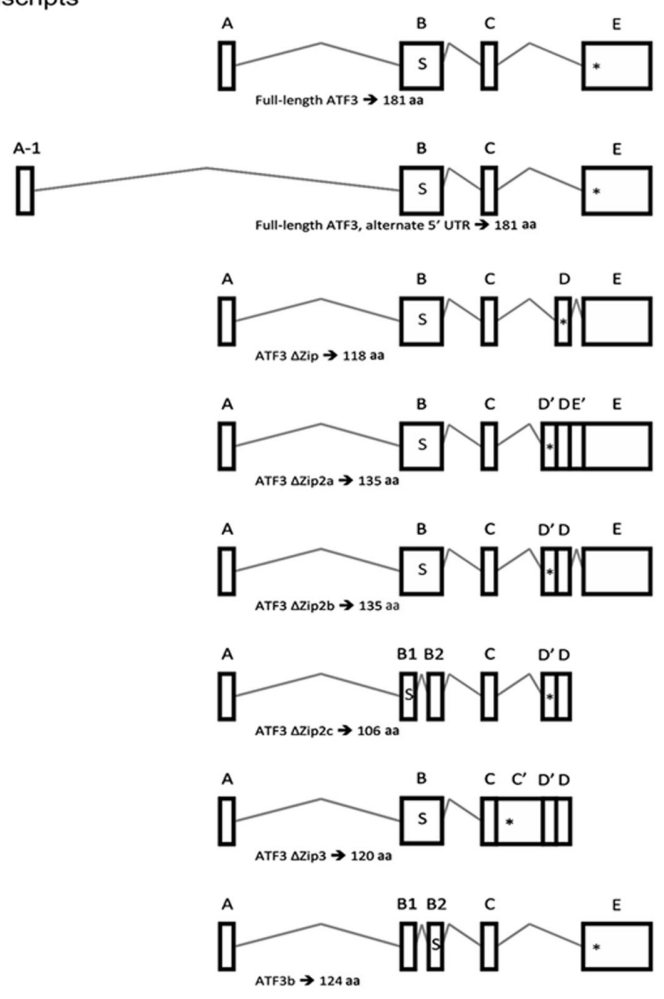

FIGURE 2 | Activating transcription factor 3 (ATF3) gene and protein structure. (A) A schematic representation of ATF3 gene structure and transcript splice variants. The human ATF3 gene spans approximately $56 \mathrm{~kb}$ on chromosome 1q32.3, and comprises six exons. This schematic adopts the exon nomenclature used by other research groups (Hashimoto et al., 2002; Pan et al., 2003; Hartman et al., 2004). The start codon, denoted by the letter "s," is located within exon B. The respective in-frame stop codons are denoted by " $*$ " within each transcript. Note that the two transcripts which give rise to full-length ATF3 use different promoters, $\mathrm{P} 1$ and $\mathrm{P} 2$, and vary only

\section{B ATF3 transcribed protein domains}

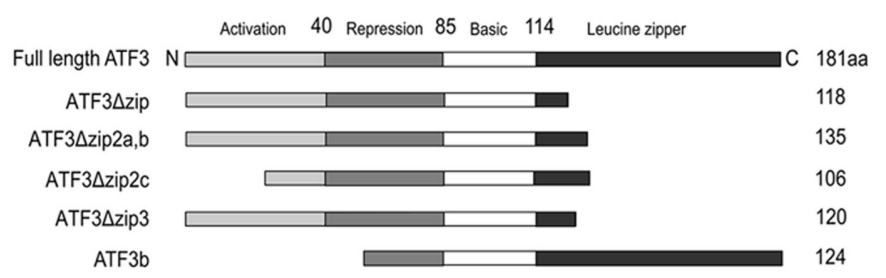

in their $5^{\prime}$ untranslated region owing to the incorporation of exon $A-1$ or $A$, respectively. $\mathrm{P} 1$ is non-canonical, lying some $\sim 43.5 \mathrm{~kb}$ upstream of $\mathrm{P} 2$, and was only recently described (Miyazaki et al., 2009). Note that exons B1 and B2 in ATF3 $\triangle$ Zip2c are not the same as those annotated B1 and B2 in ATF3b; the respective spliced fragments of exon $B$ are of different sizes and use different splice donor and acceptor sites. Exons are not shown to scale. (B) The predicted protein structure for each of the ATF3 mRNAs is shown in (A), with the activation, repression, basic, and leucine zipper regions designated. Modified from Pan et al. (2003). aa, Amino acids. amino acid sequence. However, there is another in-frame start codon downstream which, if used for initiation of translation, gives rise to a $124 \mathrm{aa}$ ATF3 isoform. The authors report that this protein, which is truncated at the amino terminus, can be detected in whole pancreas homogenate.

\section{Structure/function relationship for ATF3 protein isoforms}

Full-length ATF3 comprises 181aa, with a molecular mass of $22 \mathrm{kDa}$ (Hai et al., 1989; Chen et al., 1994; Thompson et al., 2009). The region between $40 \mathrm{aa}$ and $84 \mathrm{aa}$ is thought to exert transcriptional repression (Hsu et al., 1992), whilst the basic region leucine zipper domain, spanning the region from 88 to $147 \mathrm{aa}$ is necessary for dimerization and DNA binding (Hashimoto et al., 2002). ATF3 $\Delta$ zip and ATF3 $\Delta$ zip2 are truncated at 118aa and 135aa, respectively.
Somewhat paradoxically ATF3 $\Delta$ zip, a $14-\mathrm{kDa}$ protein, is thought to have the capacity to activate transcription despite retaining the putative transcriptional repression domain and lacking most of the basic region leucine zipper domain. This may be achieved by ATF3 $\Delta$ zip sequestering inhibitory co-factors (Chen et al., 1994). Hua et al. (2006) also reported that ATF3 $\Delta$ zip2 displaces the positive cofactor $\mathrm{CBP} / 300$ from a protein complex involved in the transcriptional control at nuclear factor- $\kappa \mathrm{B}$ (NF$\kappa \mathrm{B})$ sites in the anti-apoptotic gene cIAP2. The same ATF3 $\Delta$ zip2 protein modulates the activity of the full-length ATF3 protein during stress responses and cellular proliferation (Hashimoto et al., 2002). ATF3 $\Delta$ zip3 stimulates transcription from the asparagine synthetase promoter (Pan et al., 2003); as with the transcriptional activation effects of ATF3 $\Delta$ zip, this may be mediated through a sequestration of co-repressors away from the promoter. 
Finally, the 124aa ATF3b isoform (with N-terminal truncation) can still form homodimers, despite lacking the weak activation region and part of the repression region. These ATF3 homodimers can bind to the CRE/ATF site of the proglucagon promoter and stimulate transcription (Wang et al., 2003). It is worth noting that the prevalence and significance in vivo of the products of the numerous splice variants of ATF3 have not yet been fully established. In particular, almost nothing is known about the expression in the nervous system of the protein products of splice variants.

\section{ATF3 INDUCTION AND REGULATION}

Activating transcription factor 3 has been variously described as an immediate early gene, a stress inducible gene and an adaptive response gene (Thompson et al., 2009; Zmuda et al., 2010). It appears to play an important role in mediating the cellular response to injury and stress, but there are microarray data to show that ATF3 also enables cells to cope with intracellular and extracellular changes which are not directly harmful (Hai, 2006). In most healthy tissues ATF3 is expressed at a very low level, if at all (Hsu et al., 1991; Chen et al., 1994; Allen-Jennings et al., 2001).

The regulation of ATF3 appears to take place mainly at the translational level: there is no evidence that its activity is regulated by phosphorylation as is that of c-Jun or STAT3, for example, whose expression by neurons is also correlated with axonal regeneration. Analysis of the ATF3 promoters reveals an array of transcription factor binding sites consistent with its expression being induced by stressful stimuli and other factors. P2 contains a canonical TATA box, inducible transcription factor binding sites (e.g., for ATF/CRE, AP-1, and NF- $\kappa$ B), and cell cycle dependent sites (e.g., for E2F and Myc/Max). The alternate promoter P1 contains a non-canonical TATA box as well as ATF/CRE, AP-1, p53, E2F, and NF- $\kappa$ B binding sites. As would be expected, c-Jun/AP-1, ATF2, ATF4, ATF6, CREB, Myc, C/EBPB, Erg-1, and other transcription factors have all been shown to induce ATF3 expression (Tamura et al., 2005; Huo et al., 2006). In addition, ATF3 represses its own expression (Wolfgang et al., 2000), limiting the period of its expression in response to stressful stimuli.

The co-expression of c-Jun and ATF3 in the nervous system following traumatic injury and other stressful stimuli makes c-Jun a prime candidate for controlling ATF3 transcription. ATF3 expression is upregulated by c-Jun in rabbit reticulocytes (Weidenfeld-Baranboim et al., 2009), human vascular endothelial cells (Weidenfeld-Baranboim et al., 2009), and neuronal cell lines (Jankowski et al., 2009) but elevation of c-Jun does not appear to be a prerequisite for ATF3 upregulation in human skin fibroblasts (Abe et al., 2003) and primary sensory neurons (Tsujino et al., 2000). Another factor in the control of ATF3 induction is Jun Dimerization Protein 2 (JDP2), a ubiquitous bZip protein closely related to ATF3, which exerts its effect at the ATF/CRE and two non-canonical auto-regulatory sites, at -90 and -20 , of the ATF3 promoter (Kim et al., 2010b). JDP2 represses ATF3 expression and its ablation results in the potentiation of ATF3 expression by stressful stimuli (Weidenfeld-Baranboim et al., 2009). Interestingly, phosphorylation of JDP2 has been observed in response to such stimuli, but the significance of this remains unclear.

Studies with siRNA have shown that the transcription factor SOX11 (Jankowski et al., 2009), a member of the group C SOX
(SRY-related HMG-box) transcription factor family, positively regulates ATF3 expression in axotomized sensory neurons in vivo. ATF3 expression in astrocytes is also upregulated at the transcriptional level by NF-E2-related factor 2 (Nrf2), a transcription factor which binds to the antioxidant response element (ARE) in promoters. Treatment with Nrf2 activators and oxidants provokes ATF3 induction in astrocytes, and ATF3 expression is reduced in Nrf2-depleted cells (Kim et al., 2010b). Phosphorylation of the $\alpha$ -subunit of the eukaryotic translation initiation factor 2 (eIF2) in lung cells in response to hypoxia leads to nuclear translocation of ATF4 and a subsequent increase in ATF3 expression (Konsavage et al., 2012).

If extracellular signals are to increase ATF3 expression, signal transduction mechanisms between the cell membrane and the DNA must be activated. Mitogen-activated protein kinase (MAPK) pathways are involved in the cellular response to many external stimuli. Of these MAPK pathways, the p38 pathway, extracellular signal-regulated kinase (ERK), and the c-Jun N-terminal kinase (JNK) pathways are known to affect ATF3 (Figure 3). ATF3 expression is upregulated by both ATF2 and c-Jun, and both of these are phosphorylated by MAPK pathways. For example, the induction of ATF3 expression in colonic cancer cells treated with tolfenamic acid, a pro-apoptotic drug, is mediated by p38 activation leading to phosphorylation of ATF2 and involves the ATF/C/EBP-binding site in the ATF3 promoter (Lee et al., 2010). The p38 pathway, but not the ERK nor the JNK pathways, was also required for ATF3 expression in several cell lines exposed to anisomycin ( $\mathrm{Lu}$ et al., 2007). However, JNK activation may also be associated with ATF3 induction in cultures of primary sensory neurons (DRG and nodose ganglion cells); inhibitors of JNK reduced c-Jun phosphorylation, ATF3 upregulation, and neurite outgrowth (Lindwall et al., 2004). As those authors pointed out, it is tempting to construct a pathway involving JNK activation leading to c-Jun phosphorylation and the ATF3 upregulation but some neurons showed elevated ATF3 without pc-Jun or pJNK (Lindwall et al., 2004). The retrograde axonal transport of JNK by neurons appears to be an important part of the signaling mechanism by which an injured axon induces a cell body response, including the upregulation of ATF3 (Lindwall and Kanje, 2005). However, MAPK activation is not essential for upregulation of ATF3, at least in non-neuronal cells (Konsavage et al., 2012).

Activating transcription factor 3 expression is induced by activation of the innate and adaptive immune systems. Toll-like receptor (TLR)3, TLR4, and TLR9 agonists are potent inducers of ATF3 expression in macrophages and epithelial cells (Gilchrist et al., 2006; Suganami et al., 2009; Roussel et al., 2011) as is TCR ligation in CD4 lymphocytes (Gilchrist et al., 2008). TLR activation stimulates the JNK and p38 MAPK pathways and NF- $\mathrm{B}$ activation.

Apart from transcriptional regulation, there is now evidence that the expression of ATF3 is regulated at the post-transcriptional level by selective degradation. Double minute 2 (MDM2) is an E3 ubiquitin ligase for ATF3 and regulates ATF3 expression by promoting its degradation, at least in HCT116 (colorectal carcinoma) cells and mouse embryonic fibroblasts (Mo et al., 2010). It is not yet clear how significant this form of regulation is in injured neurons, 


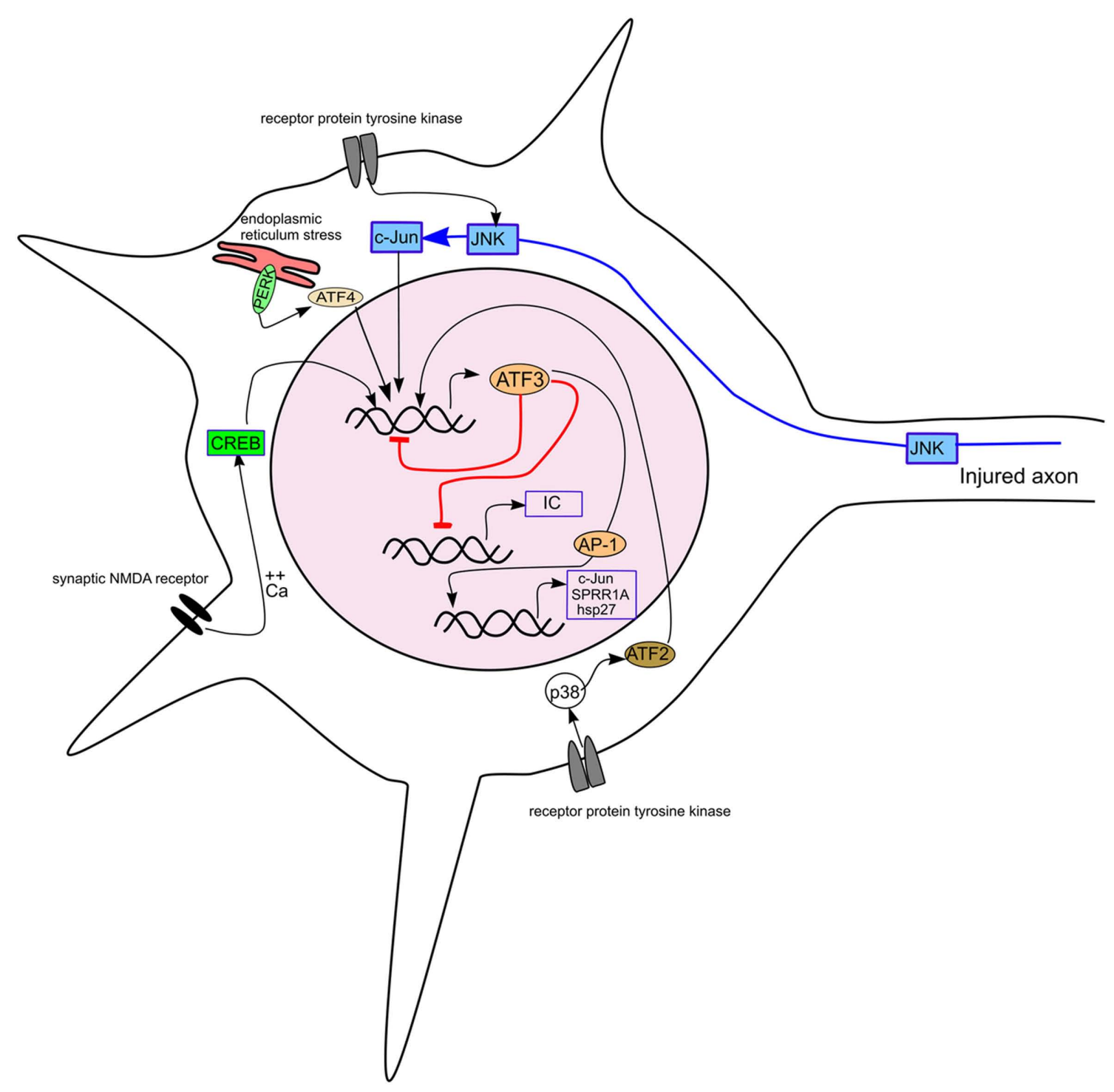

FIGURE 3 | Diagram showing the induction of ATF3 in a neuron by different stimuli and its effect on some targets relevant to axonal regeneration. The pathways inducing ATF3 expression include axotomy, receptor protein tyrosine kinase stimulation, synaptic NMDA receptor activation and endoplasmic reticulum stress. ATF3 is shown repressing its own expression and that of inflammatory cytokines (IC) and, with other AP-1 factors, activating transcription of c-Jun, SPRR1A, and hsp27. however, where there is a close correlation between ATF3 mRNA levels and nuclear ATF3 protein (Tsujino et al., 2000).

\section{INTERACTIONS WITH OTHER TRANSCRIPTION FACTORS AND GENERAL FUNCTIONS OF ATF3}

The interaction of ATF3 with many other transcription factors dramatically alters its effects on transcription (reviewed by Hai, 2006). ATF/CREB members can form heterodimers with members of other families (e.g., C/EBP and Maf families), as well as with other ATF/CREB subgroup members. c-Jun is a particularly important partner for ATF3 in the nervous system; as well as being a potential inducer of ATF3 expression, c-Jun binds to ATF3. c-Jun co-immunoprecipitates with ATF3 in extracts of reticulocytes (Hai and Curran, 1991), PC12 cells (Nakagomi et al., 2003;
Pearson et al., 2003), Neuro-2a cells (Pearson et al., 2003), suggesting that these two transcription factors can form heterodimers, at least in non-neuronal cells and "neuronal" cell lines. Importantly, both ATF3 and c-Jun are present in hypoglossal neurons after their axon was cut (Kiryu-Seo et al., 2008). Here, an unconventional mechanism of action for ATF3 and c-Jun has been proposed, in which the constitutively expressed transcription factor Sp1 (a member of the Sp/KLF family) acts as scaffold protein to bring about the association of ATF3, c-Jun, and STAT3 at the Sp1 binding sites. This notion is supported by the coimmunoprecipitation of ATF3 and c-Jun, ATF3 and Sp1, c-Jun and Sp1, and STAT3 and Sp1, but not STAT3 and c-Jun (or ATF3; Kiryu-Seo et al., 2008). A transient upregulation of JunB has been reported in axotomized neurons (Kenney and Kocsis, 1997), 
making ATF3/JunB heterodimers another possible combination regulating axonal regeneration.

It has been suggested that in regenerating liver, ATF3 in combination with c-Jun activates specific promoters containing AP-1 and CRE sites, but in combination with JunB it potently represses activation of AP-1 sites (Hsu et al., 1992). ATF3 has been implicated in the cellular response to many varied insults, including ischemia/reperfusion of the kidney or heart (Chen et al., 1996; Yin et al., 1997), liver damage (Chen et al., 1996), ventilation-induced lung damage, and many types of insult to cultured cells including hypoxia (Ameri et al., 2007) and other treatments (Lerner et al., 1996). Many circumstances that cause ATF3 expression also lead to cell death (Kim et al., 2010a; Liu et al., 2011) but ATF3 has also been found to be constitutively expressed in a number of human cancers and it is said to be associated with metastatic potential. The interaction of ATF3 with p53 is thought to facilitate apoptosis (Yan et al., 2005). It is believed that ATF3 stabilizes the p53 protein through blocking MDM2-mediated ubiquitination, nuclear export, and degradation. Protein deletion studies reveal that the 102-139aa region of ATF3 is necessary for p53 binding.

Activating transcription factor 3 is believed to have at least two key roles: as a mediator of the cellular stress response, and as a regulator of cellular proliferation. However, because the functions of ATF3 depend on the transcriptional milieu within which it is found, ATF3 can have opposite effects on different types of cell (Yin et al., 2008). Both gene delivery (Mashima et al., 2001) and gene inactivation experiments (Nawa et al., 2002) have attributed pro-apoptotic effects to ATF3, yet anti-apoptotic effects have also been described (Kawauchi et al., 2002). Similarly, ATF3 has been reported to suppress or promote cell cycle progression (Fan et al., 2002; Lv et al., 2011). In addition, in recent years its role in immune response pathways has received much attention, especially as a negative regulator of TLR family signaling in the inflammatory response (reviewed by Thompson et al., 2009). Network analysis predicts that ATF3 is part of a transcriptional complex containing members of the NF- $\kappa$ B family of transcription factors and that ATF3 can regulate the expression of inflammation-related genes including IL1 $\beta$, IL6, IL12, TNF $\alpha$, and CCL4 (Gilchrist et al., 2006). Hai (2006) proposed that ATF3 induction by various stimuli in different cell types contributes to the control of the cell death and cell cycle machineries in a context-dependent manner. The nervous system appears to be a special context in that while ATF3 tends to produce tissue dysfunction and disease progression in many types of non-neuronal cells (Hai, 2006), in the nervous system ATF3 appears to contribute to the regenerative response (Campbell et al., 2005).

One adaptive pathway in which ATF3 has been implicated is the Endoplasmic Reticulum Stress Response (ERSR; also known as the Unfolded Protein Response) which occurs in response to the pathological accumulation of unfolded or misfolded proteins within the lumen of the endoplasmic reticulum. In essence, this pathway attempts to restore normal ER protein folding and processing through several different actions including the inhibition of translation and reduction in translocation of new proteins into the ER, promotion of the export of aberrant proteins from the ER lumen to the cytosol for degradation, and the recruitment of more molecular chaperones to assist in protein folding. Ultimately, if the
ER remains stressed, the pathway will instead default to apoptosis. The ERSR is complex and is mediated by a tripartite system of transmembrane molecular sensors within the endoplasmic reticulum, namely ATF6, PERK, and IRE1 alpha. Each of these has a fairly well defined pathway, becoming activated following the detection of inappropriately folded protein within the ER lumen. ATF3 has been implicated in the PERK-mediated arm (Figure 3), which is initially protective but also has a role in inducing apoptosis via the ATF4-ATF3-CHOP cascade (Mungrue et al., 2009).

Pan et al. (2003) have presented evidence to show that ATF3 expression was enhanced in HepG2 hepatoma cells in which the ERSR pathway had been activated. There are many examples of ERSR activation in neurodegenerative diseases and following traumatic injury to the nervous system, including Parkinson's disease (Bellucci et al., 2011) and in vitro models of that condition (Holtz et al., 2006), amyotrophic lateral sclerosis (Kanekura et al., 2009), Alzheimer's disease (Salminen et al., 2009), and following peripheral nerve injury (Penas et al., 2011). In many of these cases (but not apparently Alzheimer's disease) ATF3 expression is also found in the affected neurons. However, a causal link between the ERSR and ATF3 expression usually has not been established and the effect of ATF3 within the stressed cells is uncertain. Cultured midbrain neurons treated with 6-OHDA (a model of the neurodegeneration found in Parkinson's disease) showed an ERSR and upregulated ATF3 expression but neurons from ATF3 "knockout" mice were not protected from cell death following 6-OHDA treatment (Bernstein et al., 2011). This was interpreted as indicating that the induction of an ERSR and consequent ATF3 expression was not the pathway leading to cell death in this model (it was proposed to be neuroprotective instead). However the value of this mutation for investigating ATF3 function in the nervous system has been questioned (see below).

\section{ATF3 IN NORMAL AND INJURED NEURONS INTACT NEURONS}

Activating transcription factor 3 is either not expressed or expressed at very low levels in most intact neurons in vivo. In some studies ATF3 could not be detected in the neurons of uninjured animals. For example, it has been reported that there is no immunohistochemically detectable ATF3 in the facial motor neurons of intact mice (Parsadanian et al., 2006) and that there is no signal in Western blots for ATF3 in adult rat cerebral hemisphere (Yano et al., 2008). Although ATF3 has been detected in the nuclei of a very small percentage of primary sensory neurons in DRG of uninjured rats in some studies (Averill et al., 2002), others have failed to find such cells (Tsuzuki et al., 2001; Takahashi et al., 2003; Carlton et al., 2009). A similar low number of sympathetic neurons with ATF3-positive nuclei have been found in the superior cervical ganglia of intact rats (Hyatt-Sachs et al., 2007). It seems likely that ATF3 expression by sensory and postganglionic sympathetic neurons in intact animals is infrequent enough to be overlooked in most studies and may reflect a low level of axonal injury in populations of neurons that project to exposed sites.

Cytoplasmic ATF3 has been reported in von Economo neurons in the anterior cingulate gyrus of primates including man (Stimpson et al., 2011); this is quite different from the normal pattern of ATF3 expression in which the gene is only expressed at times of 
changes in the intracellular or extracellular environment and the protein is found predominantly in the nucleus. In our experience cytoplasmic immunohistochemical signal for ATF3 in neurons is more common in mice than in rats, whereas nuclear staining is injury-specific and similar in both mice and rats. Delivery of the ATF3 gene with an amplicon vector to rat DRG neurons in culture resulted in both cytoplasmic and nuclear localization of the protein (Seijffers et al., 2006) in contrast to the nuclear localization of endogenous ATF3. The same combined pattern was also observed in vivo with neuronal ATF3 overexpression, with majority neurons showing strong cytoplasmic staining, and a minority, also nuclear translocation (Seijffers et al., 2007). It has been reported that STAT1 is necessary for nuclear expression of ATF3 in hepatocytes and pancreatic beta cells (Kim et al., 2009, 2010a). It is to be hoped that there will be similar studies involving neurons and glial cells.

\section{ATF3 IS UPREGULATED IN NEURONS PROJECTING INTO INJURED PERIPHERAL NERVES}

The most consistent observation on ATF3 expression in the nervous system is that ATF3 is upregulated by neurons with axons projecting into injured peripheral nerves, including spinal motor neurons (Tsujino et al., 2000; Figure 1A), facial motor neurons (Parsadanian et al., 2006; Shokouhi et al., 2010), primary sensory neurons (Tsujino et al., 2000; Tsuzuki et al., 2002), postganglionic sympathetic neurons (Hyatt-Sachs et al., 2007), and preganglionic parasympathetic neurons (Peddie and Keast, 2011; Figure1B). ATF3 immunoreactivity in these regenerating peripheral neurons is concentrated in the nucleus, but not the nucleolus, but cytoplasmic immunoreactivity is sometimes detectable. All DRG neurons with injuries to their peripheral axon appear to express ATF3 mRNA (Tsujino et al., 2000). ATF3 mRNA appears in DRG neurons by $6 \mathrm{~h}$ after spinal nerve transection but takes several hours longer after a more distal sciatic nerve transection (Tsujino et al., 2000). These observations on the effects of distance between the site of axotomy and the cell bodies of the injured neurons have been confirmed (Linda et al., 2011). There are two obvious explanations of the reduced time delay following spinal nerve injury: the shorter time taken for a retrograde signal to reach the cell bodies after axotomy or the more intense cell body reaction seen after more proximal axotomy (Lieberman, 1971). In addition, ATF3 is retrogradely transported in axons of peripheral nerves, as demonstrated by its accumulation proximal to a ligation (Lindwall and Kanje, 2005). Transection and crush injuries to peripheral nerve have been most often used to upregulate ATF3 in peripheral neurons but tetanic stimulation of rat sciatic nerve, which produces Wallerian degeneration in the nerve, also induces ATF3 expression in DRG neurons (none was found in naïve rats; Liang et al., 2010). Less intensive stimulation did not upregulate ATF3 in DRG neurons (Tsujino et al., 2000; Tsuzuki et al., 2001).

A key feature of the neuronal response to axotomy in DRG neurons is that this response is much more muted following injury of the central process of their axons. In the case of ATF3, this response is weaker, confined to larger neurons and more transient, disappearing by 7 days after injury (Huang et al., 2006). None the less, ATF3 upregulation is one of the more obvious effects of injury to the central processes of primary sensory neurons.
Neuronal ATF3 is also upregulated in peripheral neuropathy. Paclitaxel, a cytotoxic drug used in the treatment of cancer is associated with a peripheral neuropathy side-effect, also produces the upregulation of ATF3 in primary sensory neurons in DRG and trigeminal ganglia in experimental animals (JimenezAndrade et al., 2006; Peters et al., 2007a). However, ATF3 expression remained low in animals where no axonal degeneration was detected (Flatters and Bennett, 2006). A rat model of diabetes, which induces a peripheral neuropathy, also caused ATF3 upregulation in some DRG neurons. Injection of resiniferatoxin into the paws of rats causes a dying-back neuropathy involving nociceptive axons and is associated with ATF3 upregulation in the DRG neurons during the subsequent period when axonal regeneration occurs (Mitchell et al., 2010). Similarly, ATF3 is upregulated in motor neurons in models of amyotrophic lateral sclerosis (Malaspina et al., 2010) which also involve dying-back of axons. A plausible explanation of all these results is that each of the procedures that produce upregulation of ATF3 in neurons, with the possible exception of NGF-deprivation of sympathetic neurons, also involves some degree of axonal injury or separation from targets which, in turn, signals to the cell body to upregulate ATF3.

\section{ATF3 UPREGULATION BY PERIPHERAL NEURONS IN THE ABSENCE OF DIRECT INJURY}

Several treatments that do not involve direct injury to nerve trunks have been found to induce ATF3 in peripheral neurons. Loss of NGF support induces ATF3 expression in postganglionic sympathetic neurons (Hyatt-Sachs et al., 2007). In addition, some treatments which produce peripheral inflammation induce ATF3 in neurons. For example, injection of formalin into the footpad of rats induced an inflammatory response in the foot and induced ATF3 expression in some DRG neurons and even a few motor neurons in the spinal cord (Tsujino et al., 2000). However, Freund's complete adjuvant, when injected into the footpad, did not produce ATF3 upregulation despite the profound inflammation produced at the injection site (Tsujino et al., 2000; Segond von Banchet et al., 2009; Braz and Basbaum, 2010). Injections of capsaicin, formalin, mustard oil, or menthol into the hind paw of mice induced expression of ATF3 in distinct subpopulations of sensory neurons, an observation which was interpreted as showing that the different agents injured different populations of sensory axons (Braz and Basbaum, 2010). ATF3 was also upregulated in DRG neurons in rat models of arthritis where the extent of axonal injury is unknown (Ivanavicius et al., 2007; Christianson et al., 2010).

\section{ATF3 IS UPREGULATED BY SOME TYPES OF CNS NEURONS FOLLOWING INJURY}

Unlike neurons which project into peripheral nerves, most injured CNS neurons do not regenerate their axons although many produce local sprouts from their injured axons (Fishman and Mattu, 1993; Zeng et al., 1994; Hill et al., 2001). ATF3 is upregulated by axotomized intrinsic CNS neurons, but only by some and only under certain conditions. Among the critical factors that can reduce ATF3 expression after axotomy appear to be the distance between the site of axotomy and the neuronal cell body and the abundance of collaterals proximal to the injury site. These factors can be difficult to separate in the case of CNS neurons which 
give off collaterals at several points along their length. Cerebellar Purkinje cells which are particularly poor at regenerating axons (Anderson et al., 1998; Chaisuksunt et al., 2000) do not upregulate ATF3 after axotomy (Figure 1C).

\section{Cerebral neocortex and thalamus}

Activating transcription factor 3 is upregulated in neurons around cortical ischemic infarcts and in cortical neurons thought to project through the damaged region (Ohba et al., 2003, 2004). The same studies also find a transient (lasting a few days) upregulation of ATF3 mRNA and protein in some thalamic neurons. ATF3, and several other growth-associated molecules including GAP43, were not upregulated by corticospinal neurons after spinal cord injury but they were upregulated after intracortical axotomy (Mason et al., 2003). Together these results suggest that ATF3 is upregulated by thalamic projection neurons and by neocortical projection neurons following axotomy, but only if the injury is sufficiently proximal to the cell body.

\section{Hippocampus}

Strong ATF3 expression was identified in the nuclei of dentate gyrus neurons following injection of kainate, an excitotoxin (Francis et al., 2004). Interestingly, the CA1 pyramidal neurons, which are more susceptible to kainite neurotoxicity, do not upregulate ATF3 so strongly as dentate neurons. This may suggest that ATF3 expression following excitotoxicity is involved in the survival of neurons rather than cell death.

\section{Retina}

After optic nerve injury (Takeda et al., 2000), retinal ganglion cells show a stronger and more prolonged upregulation of ATF3 (and other growth-associated molecules; Berry et al., 2008) than most other CNS neurons. This response may be the result of the relatively proximal axotomy and/or the lack of collaterals of the injured axons. Retinal ganglion cells also show a greater capability for axonal regeneration and a greater susceptibility to cell death following axotomy than most other CNS neurons (Allcutt et al., 1984; Campbell et al., 1999, 2003), and these findings are compatible with ATF3 having a role in regulating axonal regeneration and/or in cell death in response to axonal injury. Raised intraocular pressure in a rat model of glaucoma also elevates ATF3 expression in retinal ganglion cells to an extent that correlates linearly with the degree of injury to their axons (Guo et al., 2009, 2011).

\section{Brainstem}

Pontocerebellar neurons show a prolonged (weeks) upregulation of ATF3 after axotomy (Lovas et al., 2010). The same applies to dopaminergic neurons in the substantia nigra pars compacta (Song et al., 2008), and olivocerebellar neurons following axotomy within the cerebellum (our unpublished observations).

\section{ATF3 IN TREATMENT-STIMULATED, REGENERATING CNS NEURONS}

Since most intrinsic mammalian CNS neurons do not regenerate their axons (Ramon y Cajal, 1928; Bolsover et al., 2008) the relationship between ATF3 expression and regeneration can usually only be studied in models with an artificially induced regenerative response. One exception is the mammalian optic nerve where a very small percentage of axons can regenerate after injury even without further stimulus (Campbell et al., 1999). The many treatments claimed to induce axonal regeneration by CNS neurons include antibodies to myelin proteins (Raineteau et al., 1999), administration of neurotrophins (Bradbury et al., 1999), administration of chondroitinase (Bradbury et al., 2002), and the implantation of olfactory glia (Li et al., 1997). However, a particularly successful way to induce regeneration of axons of intrinsic CNS neurons involves the implantation of peripheral nerve grafts (Richardson et al., 1980), which provide good pro-regenerative environment.

None the less, even nerve grafts only induce the regeneration of axons of some types of CNS neurons (Anderson et al., 1998; Anderson and Lieberman, 1999). The neurons that can be induced to regenerate their axons have always been found to show a prolonged upregulation of ATF3. Following the implantation of nerve grafts into the thalamus more than $90 \%$ of the neurons that regenerate axons into the graft come from the thalamic reticular nucleus (TRN; Morrow et al., 1993), whereas just few thalamic projection neurons and no corticothalamic neurons regenerate their axons into the grafts. Interestingly, at early timepoints, such grafts induced the upregulation of ATF3 protein in many nearby thalamic neurons. However, after 7 days or longer most of the ATF3-positive nuclei were in TRN neurons that had regenerated their axons into the grafts (Campbell et al., 2005). Although the grafts must have axotomized many cortical neurons near their terminations in the thalamus, cortical neurons were never ATF3-positive.

Other CNS neurons that can be induced to regenerate axons into peripheral nerve grafts include retinal ganglion cells, forebrain cholinergic neurons, rubrospinal neurons, and those in the cerebellar deep nuclei. ATF3 upregulation has been reported in rubrospinal neurons regenerating axons into peripheral nerve grafts in the cervical spinal cord (Shokouhi et al., 2010) and is also found in cerebellar deep nucleus neurons that have been stimulated to mount a regenerative cell body response by the presence of a peripheral nerve graft (Figure 1D). In marked contrast, Purkinje cells, which never regenerate into such grafts, do not upregulate ATF3 (Figure 1C) ATF3 upregulation has been reported in retinal ganglion cells of Zebrafish during axonal regeneration following optic nerve crush (Saul et al., 2010).

\section{ATF3 UPREGULATION IN NEURONS WITHOUT DELIBERATE AXOTOMY Trans-synaptic effects of nerve injury}

Chronic constriction injury (CCI) of peripheral nerves is a model of chronic pain (Bennett and Xie, 1988; Vos et al., 1994) which involves inflammation - microglial activation and T-cell invasion in the central target regions of the primary nociceptive neurons, the superficial dorsal horn of the spinal cord or the spinal nucleus of the trigeminal nerve. Sciatic nerve CCI elevates ATF3 expression in L4 and L5 dorsal root ganglion neurons (Obata et al., 2003; which could be due to neuropathic pain and/or axotomy) but also in the dorsal horn (Latremoliere et al., 2008). At both sites, ATF3 expression and inflammation were attenuated by the neuroinflammation-suppressing minocycline.

\section{Stress and amphetamine administration}

The limbic part of the striatum, the nucleus accumbens, is important in the responses to psychological stress and the entire striatum 
is an important site of amphetamine action. A nearly 20 -fold increase in ATF3 mRNA expression was produced in the striatum of adult rats by the stress induced by restraint within a polythene cone for $60 \mathrm{~min}$. A non-toxic dose of amphetamine, which increases dopamine levels in the striatum, also upregulated ATF3 mRNA in the striatum but to a lesser extent (Green et al., 2008). Methamphetamine also raised ATF3 levels in the striatum of rats (Jayanthi et al., 2009).

\section{Non-axotomy signals for ATF3 expression in neurons}

Activating transcription factor 3 expression may be upregulated in neurons in response to stimuli similar to those that increase its expression in non-neuronal cells (see above) including the MAPK pathways and the ERSR, i.e., extracellular signals and endoplasmic reticulum stress. Treatment with an antiserum against NGF induces ATF3 expression in rodent postganglionic neurons (HyattSachs et al., 2007), a result which could be explained by retrograde transport of NGF suppressing ATF3 expression. A similar effect had been demonstrated previously in differentiated PC12 cells (Mayumi-Matsuda et al., 1999).

In vitro, stimulation of synaptic NMDA receptors led to a neuroprotective effect and ATF3 expression by the postsynaptic hippocampal neurons. Both effects were blocked by the NMDA antagonist MK801. Transfection of the neurons with inhibitors of CREB and CaMKIV showed that this expression of ATF3 was regulated by a nuclear calcium signaling pathway involving these molecules (Zhang et al., 2011).

Demyelination of DRG/glial cultures also leads to ATF3 upregulation by the neurons (Kiryu-Seo et al., 2010). Treatment with shRNA directed against ATF3 reduced ATF3 expression, decreased the velocity of mitochondria within demyelinated axons and increased oxidative damage in the neurons.

\section{ATF3 IN GLIAL CELLS}

Injury to the peripheral nervous system induces axonal regeneration-associated with profound phenotypic changes in glial and other non-neuronal cells including satellite cells and Schwann cells. ATF3 is strongly upregulated in peripheral glia following various types of injury. Schwann cells in the distal stump of injured sciatic nerves in rats and mice upregulate ATF3 (Hunt et al., 2004; Isacsson et al., 2005; Kataoka et al., 2007; Dahlin et al., 2008; Saito and Dahlin, 2008) in addition to c-Jun. Glial cells including Schwann and satellite cells in the superior cervical ganglion expressed ATF3 after decentralization (section of the cervical sympathetic trunk); this procedure induces the anterograde degeneration of preganglionic fibers and some of the ATF3 expression was probably around degenerating fibers (Zigmond and Vaccariello, 2007). There was a suggestion that satellite cells in DRG upregulate ATF3 following injury to the sciatic nerve (Isacsson et al., 2005; Hu et al., 2007) but this has not been generally reported, perhaps because the expression is weaker than in the sensory neurons.

Satellite cells and Schwann cells upregulated ATF3 following paclitaxel treatment (Peters et al., 2007a,b) which induced a peripheral neuropathy. Such expression may, of course, be the result of damage to the axons or direct effects on the glia. An early and significant observation was that, following dorsal root injury, ATF3 upregulation by glia around the degenerating axons within the CNS was less than that by glial cells around the same degenerating axons within the dorsal root (Hunt et al., 2004), i.e., ATF3 was upregulated by glia where axonal regeneration normally occurs but upregulated to a much lesser extent where axonal regeneration does not occur. The implication of this is that the changes in gene expression mediated by ATF3 in glia may be crucial to providing an environment suitable for regenerating axons.

The specific role of glial ATF3, upregulated after axonal injury, is subject of ongoing debate. In transformed mammary epithelial cells ATF3 enhanced fibronectin expression (Yin et al., 2010), which may exert a growth-promoting effect (Vogelezang et al., 1999). In untransformed chick fibroblasts ATF3 also repressed the expression of decorin (Perez et al., 2001; Yin et al., 2010), a TGFbbinding glycoprotein which may reduce scarring and thus promote regeneration (Davies et al., 2004). But to determine a specific role for ATF3 in glia, one would probably need a cell type-specific deletion of most of the ATF3 gene encompassing exons $\mathrm{C}$ to E, which encode all the bZip domain and large part of the repressor region.

\section{ATF3 in neuroinflammation}

Inflammation in the CNS provides a stimulus for glial ATF3 upregulation. ATF3 can be induced in macrophages and microglia by the cytokine, IL6 (Dominguez et al., 2010). Lipopolysaccharide, a highly inflammatory bacterial product, applied to the motor cortex induced ATF3 expression in the nuclei of many glial cells in the subcortical white matter (Hossain-Ibrahim et al., 2006). ATF3 is a negative regulator of TLR4, the receptor for lipopolysaccharide in such cells (Gilchrist et al., 2006) and as such might be expected to dampen down the inflammatory response of microglia.

Activating transcription factor 3 is also induced in neurons in some inflammatory states: ATF3 is upregulated in the inflamed spinal cord of animals with CCI of the sciatic nerve (see above and Dominguez et al., 2010) and in the pontine nuclei following demyelination of the pontocerebellar tract. In a patient with Marburg's variant of multiple sclerosis ATF3 was found in neurons within the pontine nuclei and neocortex (Lovas et al., 2010). A caveat is that the extent of axonal injury in such cases of demyelination remains unknown.

Neuroinflammation has been hypothesized to play a role in the genesis of some psychiatric conditions (Smith, 1992). ATF3 expression by monocytes was increased in schizophrenia and bipolar disorder (Drexhage et al., 2010; Weigelt et al., 2011). ATF3 binds to the triggering receptor expressed on myeloid cells 1 (TREM-1) promoter and may be a negative regulator of the inflammatory response (Weigelt et al., 2011) but it is not clear how this would fit in to the pathology of psychoses.

\section{WHAT IS THE FUNCTION OF NEURONAL ATF3?}

Activating transcription factor 3 has no known role in neural development or the intact nervous system; its expression appears to be to a response stimuli which are mainly stressful or pathological (Tables 1 and 2). Most direct evidence in terms of functional role comes from experiments with transgenic mice. Transgenic mice that overexpress ATF3 in sensory dorsal root ganglion neurons show enhanced rate of sensory axon regeneration following 
Table 1 | Genes and signaling pathways related to axonal regeneration that are regulated by ATF3.

\begin{tabular}{|c|c|c|}
\hline Upregulated by ATF3 & Downregulated by ATF3 & Significance for axonal regeneration \\
\hline & $\begin{array}{l}\text { Fibronectin (Yin et al., 2008) in } \\
\text { mammary epithelial cells }\end{array}$ & $\begin{array}{l}\text { Fibronectin is produced by Schwann cells and promotes } \\
\text { neurite outgrowth (Tucker and Mearow, 2008) }\end{array}$ \\
\hline & $\begin{array}{l}\text { Toll-like receptor signaling (Gilchrist } \\
\text { et al., 2006; Litvak et al., 2009) in } \\
\text { immune cells }\end{array}$ & $\begin{array}{l}\text { Inflammation around neuronal cell bodies is correlated } \\
\text { with and may stimulate axonal regeneration (Leon et al., } \\
\text { 2000; Shokouhi et al., 2010) }\end{array}$ \\
\hline & $\begin{array}{l}\text { Decorin (Perez et al., 2001) in } \\
\text { embryonic chick fibroblasts }\end{array}$ & $\begin{array}{l}\text { Decorin reduces scar formation in the CNS and } \\
\text { enhances axonal regeneration (Davies et al., 2004; } \\
\text { Minor et al., 2008) }\end{array}$ \\
\hline & $\begin{array}{l}\text { Thrombospondin } 2 \text { (Perez et al., } \\
2001 \text { ) in embryonic chick fibroblasts }\end{array}$ & $\begin{array}{l}\text { Thrombospondin-deficient mice show axonal sprouting } \\
\text { deficits (Liauw et al., 2008) }\end{array}$ \\
\hline SPRR1A (Seijffers et al., 2007) in neurons & & Promotes neurite outgrowth (Bonilla et al., 2002) \\
\hline Hsp27 (Seijffers et al., 2007) in neurons & & $\begin{array}{l}\text { Expression is associated with axonal regeneration } \\
\text { Williams et al., 2006) }\end{array}$ \\
\hline c-Jun (Seijffers et al., 2007) in neurons & & $\begin{array}{l}\text { Important regulator of axonal regeneration (Raivich } \\
\text { et al., 2004) }\end{array}$ \\
\hline DINE (Kiryu-Seo et al., 2008) in neurons & & $\begin{array}{l}\text { Required for neuromuscluar junction formation and } \\
\text { sprouting of motor axons (Nagata et al., 2010) }\end{array}$ \\
\hline
\end{tabular}

sciatic nerve injury (Seijffers et al., 2007). This is accompanied by increased expression of the genes for the regeneration-associated molecule SPRR1A (which, like ATF3, is not found in neurons during developmental axonal growth), hsp27, c-Jun, and CAP-23 but not for the prototype growth-associated molecule GAP43 or the regeneration-related transcription factor, STAT3. In vitro, ATF3 overexpression induces the growth of longer, less branched neurites from DRG neurons (Seijffers et al., 2006). Unlike peripheral injury, ATF3 overexpression alone also does not produce a pronounced cell body response comparable to that observed following injury to the peripheral axon.

Activating transcription factor 3 frequently exerts a supplementary function. Co-transfection of ATF3 and c-Jun into neuronal cell lines produced greater neurite outgrowth than transfection with individual genes (Pearson et al., 2003). Using Sp1 as a scaffold, ATF3 interacts with at least three other transcription factors, C/EBP, c-Jun, and STAT3 (Kiryu-Seo et al., 2008), each of which has been shown to be important in axonal regeneration (Raivich et al., 2004; Nadeau et al., 2005; Bareyre et al., 2011) and plays an important role for the induction of expression of damageinduced neuronal endopeptidase (DINE) in a neuroblastoma cell line (Kiryu-Seo et al., 2008). DINE is necessary for the branching of motor neuron axons within muscle during development and the formation of adequate neuromuscular junctions (Nagata et al., 2010).

In the absence of other transcription factors found in regenerating neurons (e.g., c-Jun, STAT3), the overexpression of ATF3 has relatively modest effects. For example, it is not sufficient to allow DRG axons to regenerate in the presence of CNS myelin in vitro or in the injured spinal cord in vivo. Moreover, deletion of gp130, a component of the common neurokine receptor, upstream of STAT3 phosphorylation (Habecker et al., 2009), abolishes the conditioning lesion response in explanted, sympathetic neurons, even though ATF3 is still upregulated (Hyatt-Sachs et al., 2010).
One apparent anomaly is that inflammation-related genes, which are typically downregulated by ATF3 in cells of the immune system, are upregulated in sensory and autonomic ganglia containing axotomized (and regenerating) neurons (Costigan et al., 2002; Boeshore et al., 2004). Inflammatory responses around neurons are positively correlated with axonal regeneration (Shokouhi et al., 2010) and the generation of inflammation around neuronal cell bodies has been shown to enhance regeneration of axons ( $\mathrm{Lu}$ and Richardson, 1991; Yin et al., 2003). It is possible that either the transcriptional network in axotomized neurons ameliorates the effects of ATF3 on inflammatory genes or that one function of ATF3 expression in regenerating neurons is to limit the inflammatory response, preventing neuronal cell death.

Overexpression of ATF3 is frequently neuroprotective, probably by acting as a transcriptional repressor. In vitro, delivery of ATF3 to sympathetic neurons with a viral vector (Nakagomi et al., 2003) reduced cell death resulting from growth factor deprivation and enhanced neurite outgrowth, by a pathway involving Hsp27 and Akt activation, and requiring c-Jun. Similar neuroprotective effect, this time from kainite-induced excitotoxic cell death, is also observed in the hippocampal CA1 region (Francis et al., 2004). ATF3 reduces brain damage following a cerebral ischemic insult in mice, acting as a transcriptional repressor (Zhang et al., 2011). Overexpression of ATF3 had neuroprotective effects on PC12 cells expressing mutant Huntingtin, whereas knock down of ATF3 increased toxicity (Liang et al., 2009).

An ATF3 "knockout" mouse has been used in many experiments to help determine the function of ATF3 in biological processes, particularly stress responses and cancer (Hartman et al., 2004; Khuu et al., 2007; Akram et al., 2010; Zmuda et al., 2010). The mouse was generated by replacement of exon B, containing the start codon, with a neomycin resistance gene expressed from the reverse strand (Hartman et al., 2004). The animal has no reported defects in the development of the nervous system, a result which concurs with 
Table 2 | Genes and signaling pathways regulated by ATF3 that are potentially related to neuronal death/neuroprotection.

Upregulated by ATF3
Death receptor 5 (DR5) in colonic cancer cells
(Taketani et al., 2011)
DR5 and BBC3/PUMA in stressed colorectal
cancer cells (Tanaka et al., 2011)
STAT1 in pancreatic beta cells is induced and
stabilized by ATF3 (Kim et al., 2010a)

(Kim et al., 2010a)

Hsp27 (Seijffers et al., 2007) in neurons

CHOP/GADD153 in mouse fibroblasts subject

to leucine starvation (Jiang et al., 2004)

CHOP/GADD153 levels in 6-OHDA - treated

dopaminergic neurons are partially dependent on ATF3 (Bernstein et al., 2011)

p53 is stabilized in fibroblast cell lines by ATF3

(Yan et al., 2005)

Axonal transport of mitochondria (Kiryu-Seo

et al., 2010)

C-Jun (Seijffers et al., 2007) in neurons

\section{Downregulated by ATF3}

TNFRSF10B/DR5 and BBC3/PUMA in prostate

cancer cells (Tanaka et al., 2011)

Inhibition of differentiation-1 (Id-1:

Kashiwakura et al., 2008)

\section{CHOP/GADD153 (Wolfgang et al., 1997) in}

HeLa cells

IRS2 in pancreatic beta cells (Li et al., 2008)

NRF2 in mouse mammary epithelial cells

ATF3 $\Delta$ Zip2 indirectly attenuates the anti-apoptotic effects of NF-кB signaling in rodent cell lines by displacing a positive cofactor from target genes (Hua et al., 2006)

\section{Significance for neuroprotection}

Binding of its ligand causes DR5 to trigger cell death

DR5 and BBC3/PUMA are pro-apoptotic genes (Tanaka et al., 2011)

STAT1 is involved in beta cell apoptosis in response to streptozotocin (Rasschaert et al., 2005)

ID-1 downregulation is associated with cell death in cancer cells (Wong et al., 2008)

Protects neurons from cell death following various insults (Lewis et al., 1999)

CHOP/GADD153 expression is known to induce cell cycle arrest and apoptosis in response to cellular stress factors and is also known to promote apoptosis of cancer cell lines (Maytin et al., 2001)

See above

See above

P53 can activate DNA repair or initiate apoptosis. Its expression is linked to cell death in ischemic brain injury (Hong et al., 2010).

The knockdown of ATF3 increased signs of mitochondrial damage in axons (Kiryu-Seo et al., 2010). Mitochondrial misfunction is important for axonal pathology in multiple sclerosis (Smith et al., 1999)

IRS2 is anti-apoptotic in beta cells (Li et al., 2008)

NRF2 helps cells from Parkinson's disease patients to resist oxidative stress (Cook et al., 2011) and its absent enhances the damage caused by MTPT (Innamorato et al., 2010) Important regulator of neuronal survival following axotomy (Raivich et al., 2004)

\footnotetext{
Sample citations to indicate the significance of individual genes/pathways are given. As can be seen from the cases of CHOP, DR5, and BBC3/PUMA, ATF3 can regulate genes in opposite directions in different types of cells and under different conditions. Unfortunately, few of the data refer to neurons or glial cells.
}

the finding that ATF3 is not expressed in the developing mouse cortex at embryonic day 15.5 (Dr S. Rakic, UCL, unpublished microarray data) when such events are underway.

Preliminary experiments on sciatic nerve regeneration using ATF3 mutants (Hossein-Ibrahim, unpublished) showed no significant difference in the time taken for the return of the toe spreading reflex or the return of the response to the von Frey hair stimulation of the footpad compared to that in control animals. Studies of neurite outgrowth from DRG neurons in vitro also show no obvious defect (Seijffers et al., 2006). Interestingly, ATF3 can still be detected in the nuclei of denervated Schwann cells and injured neurons using a commercially available antibody from Santa Cruz Biotechnology (Seijffers et al., 2006; Hossein-Ibrahim, Mason and Anderson, unpublished). This suggests that parts of the ATF3 protein, including those required for nuclear localization, are still expressed and coincides with a presence of a $17-\mathrm{kDa}$ ATF3-immunoreactive protein on Western Blots (Seijffers et al., 2006). However, it is uncertain whether this was a truncated form 
of ATF3 and, if so, whether it retains biological activity. It is not clear how an in-frame sequence can be generated when exon B is eliminated from the mouse ATF3 gene. The mutation has effects in non-neural cells (Hartman et al., 2004; Jiang et al., 2004; Whitmore et al., 2007; Akram et al., 2010). In some of these studies ATF3 has been reported to be absent from Western blots of the mutant cells, even with the Santa Cruz antibody (Hartman et al., 2004; Jiang et al., 2004). However, to our knowledge, no studies which have reported a phenotype for the mutant cells have reported immunohistochemically detectable ATF3 in cell nuclei, as is the case for injured neurons and Schwann cells. There is one report (Bernstein et al., 2011) of effects of the mutation on cultured neurons (CHOP levels were reduced in 6-OHDA - treated dopaminergic neurons) but the preliminary data make it unlikely that any effects of this mutation on axonal regeneration will be profound.

\section{CONCLUSION}

Although ATF3 is now widely used as marker for axotomized neurons, the complex interactions of ATF3 with other transcription factors make an assessment of its role in the injured nervous system difficult. ATF3 has been shown to be an adaptive response gene which allows cell death and cell cycle pathways in non-neuronal cells to be modulated to produce an appropriate response to mainly

\section{REFERENCES}

Abe, T., Oue, N., Yasui, W., and Ryoji, M. (2003). Rapid and preferential induction of ATF3 transcription in response to low doses of UVA light. Biochem. Biophys. Res. Commun. 310, 1168-1174.

Akram, A., Han, B., Masoom, H., Peng, C., Lam, E., Litvack, M. L., Bai, X., Shan, Y., Hai, T., Batt, J., Slutsky, A. S., Zhang, H., Kuebler, W. M., Haitsma, J. J., Liu, M., and dos Santos, C. C. (2010). Activating transcription factor 3 confers protection against ventilator-induced lung injury. Am. J. Respir. Crit. Care Med. 182, 489-500.

Allcutt, D., Berry, M., and Sievers, J. (1984). A qualitative comparison of the reactions of retinal ganglion cell axons to optic nerve crush in neonatal and adult mice. Brain Res. 318, 231-240.

Allen-Jennings, A. E., Hartman, M. G., Kociba, G. J., and Hai, T. (2001). The roles of ATF3 in glucose homeostasis. A transgenic mouse model with liver dysfunction and defects in endocrine pancreas. J. Biol. Chem. 276, 29507-29514.

Ameri, K., Hammond, E. M., Culmsee, C., Raida, M., Katschinski, D. M., Wenger, R. H., Wagner, E., Davis, R. J., Hai, T., Denko, N., and Harris, A. L. (2007). Induction of activating transcription factor 3 by anoxia is independent of $\mathrm{p} 53$ and the hypoxic

stressful stimuli. Its expression in many tissues is associated with tissue dysfunction and disease progression (Hai, 2006) but in neurons its expression is usually correlated with the responses to injury that lead to axonal regeneration and neuroprotection. One problem with understanding the role of ATF3 in the nervous system is that most studies of ATF3 function have been carried out on cultured non-neuronal cells or neuronal cell lines. It is not all clear whether ATF3 will have the same functions in such cells as in post-mitotic neurons.

The difficulties with the existing strain of knockout mice (Seijffers et al., 2006) have delayed a full evaluation of the role of ATF3 in the nervous system in vivo and the status of ATF3 expression in those animals requires clarification. Other gain of function and loss of function studies have demonstrated a modest role for ATF3 in driving the expression of other growth-related and neuroprotective genes but the generation of more sophisticated conditional knockouts in neurons, glial cells, and immune system cells will be required to elucidate all the functions of ATF3 in the nervous system.

\section{ACKNOWLEDGMENTS}

We would like to thank Dr S. Rakic for allowing us to make reference to her unpublished microarray data on gene expression in the developing rodent cortex.

neuroinflammation, and nerve regeneration. Brain Behav. Immun. 24, 1254-1267.

Bellucci, A., Navarria, L., Zaltieri, M., Falarti, E., Bodei, S., Sigala, S., Battistin, L., Spillantini, M. Missale, C., and Spano, P. (2011). Induction of the unfolded protein response by $\alpha$ synuclein in experimental models of ParkinsonGÇÖs disease. J. Neurochem. 116, 588-605.

Bennett, G. J., and Xie, Y. K. (1988). A peripheral mononeuropathy in rat that produces disorders of pain sensation like those seen in man. Pain 33, 87-107.

Bernstein, A. I., Garrison, S. P., Zambetti, G. P., and O'Malley, K. L. (2011). 6-OHDA generated ROS induces DNA damage and p53- and PUMA-dependent cell death. Mol. Neurodegener. 6, 2.

Berry, M., Ahmed, Z., Lorber, B., Douglas, M., and Logan, A. (2008). Regeneration of axons in the visual system. Restor. Neurol. Neurosci. 26, 147-174.

Boeshore, K. L., Schreiber, R. C., Vaccariello, S. A., Sachs, H. H., Salazar, R., Lee, J., Ratan, R. R., Leahy, P., and Zigmond, R. E. (2004). Novel changes in gene expression following axotomy of a sympathetic ganglion: a microarray analysis. J. Neurobiol. 59, 216-235.

Bolsover, S., Fabes, J., and Anderson, P. N. (2008). Axonal guidance molecules and the failure of axonal regeneration in the adult mammalian spinal cord. Restor. Neurol. Neurosci. 26, 117-130.

Bonilla, I. E., Tanabe, K., and Strittmatter, S. M. (2002). Small proline-rich repeat protein $1 \mathrm{~A}$ is expressed by axotomized neurons and promotes axonal outgrowth. J. Neurosci. 22, 1303-1315.

Bradbury, E. J., Khemani, S., Von, R., King Priestley, J. V., and McMahon, S. B. (1999). NT-3 promotes growth of lesioned adult rat sensory axons ascending in the dorsal columns of the spinal cord. Eur. J. Neurosci. 11, 3873-3883.

Bradbury, E. J., Moon, L. D., Popat, R. J., King, V. R., Bennett, G. S., Patel P. N., Fawcett, J. W., and McMahon, S. B. (2002). Chondroitinase $\mathrm{ABC}$ promotes functional recovery after spinal cord injury. Nature 416, 636-640.

Braz, J. M., and Basbaum, A. I. (2010). Differential ATF3 expression in dorsal root ganglion neurons reveals the profile of primary afferents engaged by diverse noxious chemical stimuli. Pain 150, 290-301.

Campbell, G., Holt, J. K. L., Shotton, H. R., Anderson, P. N., Bavetta, S., and Lieberman, A. R. (1999). Spontaneous regeneration after optic nerve injury in adult rat. Neuroreport 10, 3955-3960. 
Campbell, G., Hutchins, K., Winterbottom, J., Grenningloh, G., Lieberman, A. R., and Anderson, P. N. (2005). Upregulation of activating transcription factor 3 (ATF3) by intrinsic CNS neurons regenerating axons into peripheral nerve grafts. Exp. Neurol. 192, 340-347.

Campbell, G., Kitching, J., Anderson, P. N., and Lieberman, A. R. (2003). Different effects of astrocytes and Schwann cells on regenerating retinal axons. Neuroreport 14, 2085-2088.

Carlton, S. M., Du, J., Tan, H. Y., Nesic, O., Hargett, G. L., Bopp, A. C., Yamani, A., Lin, Q., Willis, W. D., and Hulsebosch, C. E. (2009). Peripheral and central sensitization in remote spinal cord regions contribute to central neuropathic pain after spinal cord injury. Pain 147, 265-276.

Chaisuksunt, V., Zhang, Y., Anderson, P. N., Campbell, G., Vaudano, E., Schachner, M., and Lieberman, A. R. (2000). Patterns of expression and distribution of mRNAs for L1, CHL1, c-Jun and GAP-43 in identified regenerating neurons of the cerebellum and brainstem of the adult rat. Neuroscience 100, 87-108.

Chen, B. P., Liang, G., Whelan, J., and Hai, T. (1994). ATF3 and ATF3 delta Zip. Transcriptional repression versus activation by alternatively spliced isoforms. J. Biol. Chem. 269, 15819-15826.

Chen, B. P., Wolfgang, C. D., and Hai, T. (1996). Analysis of ATF3, a transcription factor induced by physiological stresses and modulated by gadd153/Chop10. Mol. Cell. Biol. 16, 1157-1168.

Christianson, C. A., Corr, M., Firestein, G. S., Mobargha, A., Yaksh, T. L., and Svensson, C. I. (2010). Characterization of the acute and persistent pain state present in $\mathrm{K} / \mathrm{BxN}$ serum transfer arthritis. Pain 151, 394-403.

Cook, A. L., Vitale, A. M., Ravishankar, S., Matigian, N., Sutherland, G. T., Shan, J., Sutharsan, R., Perry, C., Silburn, P. A., Mellick, G. D., Whitelaw, M. L., Wells, C. A., Mackay-Sim, A., and Wood, S. A. (2011). NRF2 activation restores disease related metabolic deficiencies in olfactory neurosphere-derived cells from patients with sporadic Parkinson's disease. PLoS ONE 6, e21907. doi:10.1371/journal.pone.0021907

Costigan, M., Befort, K., Karchewski, L., Griffin, R. S., D’Urso, D., Allchorne, A., Sitarski, J., Mannion, J. W., Pratt, R. E., and Woolf, C. J. (2002). Replicate high-density rat genome oligonucleotide microarrays reveal hundreds of regulated genes in the dorsal root ganglion after peripheral nerve injury. BMC Neurosci. 3, 16. doi:10.1186/1471-2202-3-16

Dahlin, L. B., Stenberg, L., Luthman, H., and Thomsen, N. O. (2008). Nerve compression induces activating transcription factor 3 in neurons and Schwann cells in diabetic rats. Neuroreport 19, 987-990.

Davies, J. E., Tang, X., Denning, J. W., Archibald, S. J., and Davies, S. J. (2004). Decorin suppresses neurocan, brevican, phosphacan and NG2 expression and promotes axon growth across adult rat spinal cord injuries. Eur. J. Neurosci. 19, 1226-1242.

Dominguez, E., Mauborgne, A., Mallet, J., Desclaux, M., and Pohl, M. (2010). SOCS3-mediated blockade of JAK/STAT3 signaling pathway reveals its major contribution to spinal cord neuroinflammation and mechanical allodynia after peripheral nerve injury. J. Neurosci. 30, 5754-5766.

Drexhage, R. C., van der HeulNieuwenhuijsen, L., Padmos, R. C., van, B. N., Cohen, D., Versnel, M. A. Nolen, W. A., and Drexhage, H. A. (2010). Inflammatory gene expression in monocytes of patients with schizophrenia: overlap and difference with bipolar disorder. A study in naturalistically treated patients. Int. J. Neuropsychopharmacol. 13, 1369-1381.

Fan, F., Jin, S., Amundson, S. A., Tong, T., Fan, W., Zhao, H., Zhu, X., Mazzacurati, L., Li, X., Petrik, K. L., Fornace, A. J. Jr., Rajasekaran, B., and Zhan, Q. (2002). ATF3 induction following DNA damage is regulated by distinct signaling pathways and over-expression of ATF3 protein suppresses cells growth. Oncogene 21, 7488-7496.

Fishman, P. S., and Mattu, A. (1993). Fate of severed cortical projection axons. J. Neurotrauma 10, 457-470.

Flatters, S. J., and Bennett, G. J. (2006). Studies of peripheral sensory nerves in paclitaxel-induced painful peripheral neuropathy: evidence for mitochondrial dysfunction. Pain 122, 245-257.

Francis, J. S., Dragunow, M., and During, M. J. (2004). Over expression of ATF-3 protects rat hippocampal neurons from in vivo injection of kainic acid. Brain Res. Mol. Brain Res. 124, 199-203.

Gilchrist, M., Henderson, W. R. Jr., Clark, A. E., Simmons, R. M., Ye, X., Smith, K. D., and Aderem, A. (2008). Activating transcription factor 3 is a negative regulator of allergic pulmonary inflammation. J. Exp. Med. 205, 2349-2357.

Gilchrist, M., Thorsson, V., Li, B., Rust, A. G., Korb, M., Roach, J. C., Kennedy, K., Hai, T., Bolouri, H., and Aderem, A. (2006). Systems biology approaches identify ATF3 as a negative regulator of Toll-like receptor 4 . Nature 441, 173-178.

Green, T. A., Alibhai, I. N., Unterberg, S., Neve, R. L., Ghose, S., Tamminga, C. A., and Nestler, E. J. (2008). Induction of activating transcription factors (ATFs) ATF2, ATF3, and ATF4 in the nucleus accumbens and their regulation of emotional behavior. $J$. Neurosci. 28, 2025-2032.

Guo, Y., Johnson, E., Cepurna, W., Jia, L. Dyck, J., and Morrison, J. C. (2009). Does elevated intraocular pressure reduce retinal TRKB-mediated survival signaling in experimental glaucoma? Exp. Eye Res. 89, 921-933.

Guo, Y., Johnson, E. C., Cepurna, W. O. Dyck, J. A., Doser, T., and Morrison, J. C. (2011). Early gene expression changes in the retinal ganglion cell layer of a rat glaucoma model. Invest. Ophthalmol. Vis. Sci. 52, 1460-1473.

Habecker, B. A., Sachs, H. H., Rohrer H., and Zigmond, R. E. (2009). The dependence on gp130 cytokines of axotomy induced neuropeptide expression in adult sympathetic neurons. Dev. Neurobiol. 69, 392-400.

Hai, T. (2006). "The ATF transcription factors in cellular adaptive responses," in Gene Expression and Regulation, ed. J. Ma (New York: Springer), 329-340.

Hai, T., and Curran, T. (1991). Crossfamily dimerization of transcription factors Fos/Jun and ATF/CREB alters DNA binding specificity. Proc. Natl. Acad. Sci. U.S.A. 88, 3720-3724.

Hai, T., and Hartman, M. G. (2001). The molecular biology and nomenclature of the activating transcription factor/cAMP responsive element binding family of transcription factors: activating transcription factor proteins and homeostasis. Gene 273, 1-11.

Hai, T. W., Liu, F., Coukos, W. J., and Green, M. R. (1989). Transcription factor ATF cDNA clones: an extensive family of leucine zipper proteins able to selectively form DNAbinding heterodimers. Genes Dev. 3 , 2083-2090.

Hartman, M. G., Lu, D., Kim, M. L., Kociba, G. J., Shukri, T., Buteau, J., Wang, X., Frankel, W. L., Guttridge, D., Prentki, M., Grey, S. T. Ron, D., and Hai, T. (2004). Role for activating transcription factor 3 in stress-induced beta-cell apoptosis. Mol. Cell. Biol. 24, 5721-5732.
Hashimoto, Y., Zhang, C., Kawauchi, J., Imoto, I., Adachi, M. T., Inazawa, J., Amagasa, T., Hai, T., and Kitajima, S. (2002). An alternatively spliced isoform of transcriptional repressor ATF3 and its induction by stress stimuli. Nucleic Acids Res. 30, 2398-2406.

Hill, C. E., Beattie, M. S., and Bresnahan, J. C. (2001). Degeneration and sprouting of identified descending supraspinal axons after contusive spinal cord injury in the rat. Exp. Neurol. 171, 153-169.

Holtz, W. A., Turetzky, J. M., Jong, Y. J., and O’Malley, K. L. (2006). Oxidative stress-triggered unfolded protein response is upstream of intrinsic cell death evoked by Parkinsonian mimetics. J. Neurochem. 99, 54-69.

Hong, L. Z., Zhao, X. Y., and Zhang, H. L. (2010). p53-Mediated neuronal cell death in ischemic brain injury. Neurosci. Bull. 26, 232-240.

Hossain-Ibrahim, M. K., Rezajooi, K., MacNally, J. K., Mason, M. R., Lieberman, A. R., and Anderson, P. N. (2006). Effects of lipopolysaccharide-induced inflammation on expression of growthassociated genes by corticospinal neurons. BMC Neurosci. 7, 8. doi:10.1186/1471-2202-7-8

Hsu, J. C., Bravo, R., and Taub, R. (1992). Interactions among LRF-1, JunB, c-Jun, and c-Fos define a regulatory program in the G1 phase of liver regeneration. Mol. Cell. Biol. 12, 4654-4665.

Hsu, J. C., Laz, T., Mohn, K. L., and Taub, R. (1991). Identification of LRF-1, a leucine-zipper protein that is rapidly and highly induced in regenerating liver. Proc. Natl. Acad. Sci. U.S.A. 88, 3511-3515.

Hu, P., Bembrick, A. L., Keay, K. A., and McLachlan, E. M. (2007). Immune cell involvement in dorsal root ganglia and spinal cord after chronic constriction or transection of the rat sciatic nerve. Brain Behav. Immun. 21, 599-616.

Hua, B., Tamamori-Adachi, M., Luo, Y., Tamura, K., Morioka, M. Fukuda, M., Tanaka, Y., and Kitajima, S. (2006). A splice variant of stress response gene ATF3 counteracts NF-kappaB-dependent anti-apoptosis through inhibiting recruitment of CREB-binding protein/p300 coactivator. J. Biol. Chem. 281, 1620-1629.

Huang, W. L., Robson, D., Liu, M. C., King, V. R., Averill, S., Shortland, P. J., and Priestley, J. V. (2006) Spinal cord compression and dorsal root injury cause up-regulation of activating transcription factor-3 
in large-diameter dorsal root ganglion neurons. Eur. J. Neurosci. 23, 273-278.

Hunt, D., Hossain-Ibrahim, K., Mason, M. R., Coffin, R. S., Lieberman, A. R., Winterbottom, J., and Anderson, P. N. (2004). ATF3 upregulation in glia during Wallerian degeneration: differential expression in peripheral nerves and CNS white matter. BMC Neurosci. 5, 9. doi:10.1186/1471-2202-5-9

Huo, J. S., McEachin, R. C., Cui, T. X., Duggal, N. K., Hai, T., States, D. J., and Schwartz, J. (2006). Profiles of growth hormone $(\mathrm{GH})$-regulated genes reveal timedependent responses and identify a mechanism for regulation of activating transcription factor 3 by GH. J. Biol. Chem. 281, 4132-4141.

Hyatt-Sachs, H., Rohrer, H., and Zigmond, R. E. (2010). The conditioning lesion effect on sympathetic neurite outgrowth is dependent on gp130 cytokines. Exp. Neurol. 223, 516-522.

Hyatt-Sachs, H., Schreiber, R. C., Shoemaker, S. E., Sabe, A., Reed, E., and Zigmond, R. E. (2007). Activating transcription factor 3 induction in sympathetic neurons after axotomy: response to decreased neurotrophin availability. Neuroreport 150, 887-897.

Innamorato, N. G., Jazwa, A., Rojo, A. I., Garcia, C., Fernandez-Ruiz, J., Grochot-Przeczek, A., Stachurska, A., Jozkowicz, A., Dulak, J., and Cuadrado, A. (2010). Different susceptibility to the Parkinson's toxin MPTP in mice lacking the redox master regulator $\mathrm{Nrf} 2$ or its target gene heme oxygenase-1. PLoS ONE 5, e11838. doi:10.1371/journal.pone. 0011838

Isacsson, A., Kanje, M., and Dahlin, L. B. (2005). Induction of activating transcription factor 3 (ATF3) by peripheral nerve compression. Scand. J. Plast. Reconstr. Surg. Hand Surg. 39, 65-72.

Ivanavicius, S. P., Ball, A. D., Heapy, C. G., Westwood, F. R., Murray, F., and Read, S. J. (2007). Structural pathology in a rodent model of osteoarthritis is associated with neuropathic pain: increased expression of ATF-3 and pharmacological characterisation. Pain 128, 272-282.

Jankowski, M. P., McIlwrath, S. L., Jing, X., Cornuet, P. K., Salerno, K. M., Koerber, H. R., and Albers, K. M. (2009). Sox11 transcription factor modulates peripheral nerve regeneration in adult mice. Brain Res. 1256, 43-54.
Jayanthi, S., McCoy, M. T., Beauvais, G., Ladenheim, B., Gilmore, K. Wood, W. III, Becker, K., and Cadet, J. L. (2009). Methamphetamine induces dopamine D1 receptordependent endoplasmic reticulum stress-related molecular events in the rat striatum. PLoS ONE 4, e6092. doi:10.1371/journal.pone.0006092

Jiang, H. Y., Wek, S. A., McGrath, B. C., Lu, D., Hai, T., Harding, H. P., Wang, X., Ron, D., Cavener, D. R., and Wek, R. C. (2004). Activating transcription factor 3 is integral to the eukaryotic initiation factor 2 kinase stress response. Mol. Cell. Biol. 24, 1365-1377.

Jimenez-Andrade, J. M., Peters, C. M., Mejia, N. A., Ghilardi, J. R., Kuskowski, M. A., and Mantyh, P. W. (2006). Sensory neurons and their supporting cells located in the trigeminal, thoracic and lumbar ganglia differentially express markers of injury following intravenous administration of paclitaxel in the rat. Neurosci. Lett. 405, 62-67.

Kanekura, K., Suzuki, H., Aiso, S., and Matsuoka, M. (2009). ER stress and unfolded protein response in amyotrophic lateral sclerosis. Mol. Neurobiol. 39, 81-89.

Kashiwakura, Y., Ochiai, K., Watanabe, M., Abarzua, F., Sakaguchi, M., Takaoka, M., Tanimoto, R., Nasu, Y., Huh, N. H., and Kumon, H. (2008). Down-regulation of inhibition of differentiation-1 via activation of activating transcription factor 3 and Smad regulates REIC/Dickkopf-3induced apoptosis. Cancer Res. 68, 8333-8341.

Kataoka, K., Kanje, M., and Dahlin, L. B. (2007). Induction of activating transcription factor 3 after different sciatic nerve injuries in adult rats. Scand. J. Plast. Reconstr. Surg. Hand Surg. 41, 158-166.

Kawauchi, J., Zhang, C., Nobori, K., Hashimoto, Y., Adachi, M. T., Noda, A., Sunamori, M., and Kitajima, S. (2002). Transcriptional repressor activating transcription factor 3 protects human umbilical vein endothelial cells from tumor necrosis factor-alpha-induced apoptosis through down-regulation of p53 transcription. J. Biol. Chem. 277, 39025-39034.

Kenney, A. M., and Kocsis, J. D. (1997). Temporal variability of Jun family transcription factor levels in peripherally or centrally transected adult rat dorsal root ganglia. Brain Res. Mol. Brain Res. 52, 53-61.

Khuu, C. H., Barrozo, R. M., Hai, T., and Weinstein, S. L. (2007). Activating transcription factor 3
(ATF3) represses the expression of CCL4 in murine macrophages. $\mathrm{Mol}$. Immunol. 44, 1598-1605.

Kim, J. Y., Lee, S. H., Song, E. H., Park, Y. M., Lim, J. Y., Kim, D. J. Choi, K. H., Park, S. I., Gao, B., and Kim, W. H. (2009). A critical role of STAT1 in streptozotocin-induced diabetic liver injury in mice: controlled by ATF3. Cell. Signal. 21, 1758-1767.

Kim, J. Y., Song, E. H., Lee, S., Lim, J. H., Choi, J. S., Koh, I. U., Song, J., and Kim, W. H (2010a). The induction of STAT1 gene by activating transcription factor 3 contributes to pancreatic betacell apoptosis and its dysfunction in streptozotocin-treated mice. Cell. Signal. 22, 1669-1680.

Kim, K. H., Jeong, J. Y., Surh, Y. J., and Kim, K. W. (2010b). Expression of stress-response ATF3 is mediated by Nrf2 in astrocytes. Nucleic Acids Res. $38,48-59$.

Kiryu-Seo, S., Kato, R., Ogawa, T., Nakagomi, S., Nagata, K., and Kiyama, H. (2008). Neuronal injury-inducible gene is synergistically regulated by ATF3, c-Jun, and STAT3 through the interaction with $\mathrm{Spl}$ in damaged neurons. J. Biol. Chem. 283, 6988-6996.

Kiryu-Seo, S., Ohno, N., Kidd, G. J., Komuro, H., and Trapp, B. D. (2010). Demyelination increases axonal stationary mitochondrial size and the speed of axonal mitochondrial transport. J. Neurosci. 30, 6658-6666.

Konsavage, W. M., Zhang, L., Wu, Y., and Shenberger, J. S. (2012). Hyperoxiainduced activation of the integrated stress response in the newborn rat lung. Am. J. Physiol. Lung Cell Mol. Physiol. 302, L27-L35.

Latremoliere, A., Mauborgne, A., Masson, J., Bourgoin, S., Kayser, V., Hamon, M., and Pohl, M. (2008). Differential implication of proinflammatory cytokine interleukin-6 in the development of cephalic versus extracephalic neuropathic pain in rats. J. Neurosci. 28, 8489-8501.

Lee, S. H., Bahn, J. H., Whitlock, N. C., and Baek, S. J. (2010). Activating transcription factor 2 (ATF2) controls tolfenamic acid-induced ATF3 expression via MAP kinase pathways. Oncogene 29, 5182-5192.

Leon, S., Yin, Y., Nguyen, J., Irwin, N. and Benowitz, L. I. (2000). Lens injury stimulates axon regeneration in the mature rat optic nerve. J. Neurosci. 20, 4615-4626.

Lerner, A., Clayton, L. K., Mizoguchi, E., Ghendler, Y., van, E. W., Koyasu, S., Bhan, A. K., and Reinherz,
E. L. (1996). Cross-linking of T-cell receptors on double-positive thymocytes induces a cytokine-mediated stromal activation process linked to cell death. EMBO J. 15, 5876-5887.

Lewis, S. E., Mannion, R. J., White, F. A., Coggeshall, R. E., Beggs, S., Costigan, M., Martin, J. L., Dillmann, W. H., and Woolf, C. J. (1999). A role for HSP27 in sensory neuron survival. $J$. Neurosci. 19, 8945-8953.

Li, D., Yin, X., Zmuda, E. J., Wolford, C. C., Dong, X., White, M. F., and Hai, T. (2008). The repression of IRS2 gene by ATF3, a stress-inducible gene, contributes to pancreatic beta-cell apoptosis. Diabetes 57, 635-644.

Li, Y., Field, P. M., and Raisman, G. (1997). Repair of adult rat corticospinal tract by transplants of olfactory ensheathing cells. Science 277 , 2000-2002.

Liang, L., Wang, Z., Lu, N., Yang, J., Zhang, Y., and Zhao, Z. (2010). Involvement of nerve injury and activation of peripheral glial cells in tetanic sciatic stimulation-induced persistent pain in rats. J. Neurosci. Res. 88, 2899-2910.

Liang, Y., Jiang, H., Ratovitski, T., Jie, C., Nakamura, M., Hirschhorn, R. R., Wang, X., Smith, W. W., Hai, T., Poirier, M. A., and Ross, C. A. (2009). ATF3 plays a protective role against toxicity by $\mathrm{N}$-terminal fragment of mutant huntingtin in stable $\mathrm{PC} 12$ cell line. Brain Res. 1286, 221-229.

Liauw, J., Hoang, S., Choi, M., Eroglu, C., Choi, M., Sun, G. H., Percy, M., Wildman-Tobriner, B., Bliss, T., Guzman, R. G., Barres, B. A., and Steinberg, G. K. (2008). Thrombospondins 1 and 2 are necessary for synaptic plasticity and functional recovery after stroke. J. Cereb. Blood Flow Metab. 28, 1722-1732.

Lieberman, A. R. (1971). The axon reaction: a review of the principal features of perikaryal responses to axon injury. Int. Rev. Neurobiol. 14, 49-124.

Linda, H., Skold, M. K., and Ochsmann, T. (2011). Activating transcription factor 3, a useful marker for regenerative response after nerve root injury. Front. Neurol. 2:30. doi:10.3389/fneur.2011.00030

Lindwall, C., Dahlin, L., Lundborg, G., and Kanje, M. (2004). Inhibition of c-Jun phosphorylation reduces axonal outgrowth of adult rat nodose ganglia and dorsal root ganglia sensory neurons. Mol. Cell. Neurosci. 27, 267-279.

Lindwall, C., and Kanje, M. (2005). Retrograde axonal transport of JNK signaling molecules influence injury induced nuclear changes in $\mathrm{p}$-c-Jun 
and ATF3 in adult rat sensory neurons. Mol. Cell. Neurosci. 29, 269-282.

Litvak, V., Ramsey, S. A., Rust, A. G., Zak, D. E., Kennedy, K. A., Lampano, A. E., Nykter, M., Shmulevich, I., and Aderem, A. (2009). Function of C/EBPdelta in a regulatory circuit that discriminates between transient and persistent TLR4-induced signals. Nat. Immunol. 10, 437-443.

Liu, G., Su, L., Hao, X., Zhong, N., Zhong, D., Singhal, S., and Liu, X. (2011). Salermide upregulates death receptor 5 expression through the ATF4-ATF3-CHOP axis and leads to apoptosis in human cancer cells. J. Cell. Mol. Med. doi: 10.1111/j.15824934.2011.01401.x. [Epub ahead of print].

Lovas, G., Nielsen, J. A., Johnson, K. R., and Hudson, L. D. (2010). Alterations in neuronal gene expression profiles in response to experimental demyelination and axonal transection. Mult. Scler. 16, 303-316.

Lu, D., Chen, J., and Hai, T. (2007). The regulation of ATF3 gene expression by mitogen-activated protein kinases. Biochem. J. 401, 559-567.

Lu, X., and Richardson, P. M. (1991). Inflammation near the nerve cell body enhances axonal regeneration. J. Neurosci. 11, 972-978.

Lv, D., Meng, D., Zou, F. F., Fan, L., Zhang, P., Yu, Y., and Fang, J. (2011). Activating transcription factor 3 regulates survivability and migration of vascular smooth muscle cells. IUBMB Life 63, 62-69.

Malaspina, A., Ngoh, S. F., Ward, R. E., Hall, J. C., Tai, F. W., Yip, P. K., Jones, C., Jokic, N., Averill, S. A., Michael-Titus, A. T., and Priestley, J. V. (2010). Activation transcription factor-3 activation and the development of spinal cord degeneration in a rat model of amyotrophic lateral sclerosis. Neuroreport 169, 812-827.

Mashima, T., Udagawa, S., and Tsuruo, T. (2001). Involvement of transcriptional repressor ATF3 in acceleration of caspase protease activation during DNA damaging agentinduced apoptosis. J. Cell. Physiol. 188, 352-358.

Mason, M. R., Lieberman, A. R., and Anderson, P. N. (2003). Corticospinal neurons up-regulate a range of growth-associated genes following intracortical, but not spinal, axotomy. Eur. J. Neurosci. 18, 789-802.

Maytin, E. V., Ubeda, M., Lin, J. C., and Habener, J. F. (2001). Stress-inducible transcription factor CHOP/gadd153 induces apoptosis in mammalian cells via p38 kinase-dependent and -independent mechanisms. Exp. Cell Res. 267, 193-204.

Mayumi-Matsuda, K., Kojima, S., Nakayama, T., Suzuki, H., and Sakata, T. (1999). Scanning gene expression during neuronal cell death evoked by nerve growth factor depletion. Biochim. Biophys. Acta 1489, 293-302.

Minor, K., Tang, X., Kahrilas, G., Archibald, S. J., Davies, J. E., and Davies, S. J. (2008). Decorin promotes robust axon growth on inhibitory CSPGs and myelin via a direct effect on neurons. Neurobiol. Dis. 32, 88-95.

Mitchell, K., Bates, B. D., Keller, J. M., Lopez, M., Scholl, L., Navarro, J., Madian, N., Haspel, G., Nemenov, M. I., and Iadarola, M. J. (2010). Ablation of rat TRPV1-expressing Adelta/C-fibers with resiniferatoxin: analysis of withdrawal behaviors, recovery of function and molecular correlates. Mol. Pain 6, 94.

Miyazaki, K., Inoue, S., Yamada, K., Watanabe, M., Liu, Q., Watanabe, T., Adachi, M. T., Tanaka, Y., and Kitajima, S. (2009). Differential usage of alternate promoters of the human stress response gene ATF3 in stress response and cancer cells. Nucleic Acids Res. 37, 1438-1451.

Mo, P., Wang, H., Lu, H., Boyd, D. D., and Yan, C. (2010). MDM2 mediates ubiquitination and degradation of activating transcription factor 3 . J. Biol. Chem. 285, 26908-26915.

Morrow, D. R., Campbell, G., Lieberman, A. R., and Anderson, P. N. (1993). Differential regenerative growth of CNS axons into tibial and peroneal nerve grafts in the thalamus of adult rats. Exp. Neurol. 120,60-69.

Mungrue, I. N., Pagnon, J., Kohannim, O., Gargalovic, P. S., and Lusis, A. J. (2009). CHAC1/MGC4504 is a novel proapoptotic component of the unfolded protein response, downstream of the ATF4-ATF3CHOP cascade. J. Immunol. 182, 466-476.

Nadeau, S., Hein, P., Fernandes, K. J., Peterson, A. C., and Miller, F. D. (2005). A transcriptional role for $\mathrm{C} / \mathrm{EBP}$ beta in the neuronal response to axonal injury. Mol. Cell. Neurosci. 29, 525-535.

Nagata, K., Kiryu-Seo, S., Maeda, M., Yoshida, K., Morita, T., and Kiyama, H. (2010). Damage-induced neuronal endopeptidase is critical for presynaptic formation of neuromuscular junctions. J. Neurosci. 30, 6954-6962.

Nakagomi, S., Suzuki, Y., Namikawa, K., Kiryu-Seo, S., and Kiyama, H.
(2003). Expression of the activating transcription factor 3 prevents cJun N-terminal kinase-induced neuronal death by promoting heat shock protein 27 expression and Akt activation. J. Neurosci. 23, 5187-5196.

Nawa, T., Nawa, M. T., Adachi, M. T. Uchimura, I., Shimokawa, R., Fujisawa, K., Tanaka, A., Numano, F. and Kitajima, S. (2002). Expression of transcriptional repressor ATF3/LRF1 in human atherosclerosis: colocalization and possible involvement in cell death of vascular endothelial cells. Atherosclerosis 161, 281-291.

Obata, K., Yamanaka, H., Fukuoka, T. Yi, D., Tokunaga, A., Hashimoto, N., Yoshikawa, H., and Noguchi, K. (2003). Contribution of injured and uninjured dorsal root ganglion neurons to pain behavior and the changes in gene expression following chronic constriction injury of the sciatic nerve in rats. Pain 101, 65-77.

Ohba, N., Kiryu-Seo, S., Maeda, M. Muraoka, M., Ishii, M., and Kiyama, H. (2004). Expression of damageinduced neuronal endopeptidase (DINE) mRNA in peri-infarct cortical and thalamic neurons following middle cerebral artery occlusion. $J$. Neurochem. 91, 956-964.

Ohba, N., Maeda, M., Nakagomi, S. Muraoka, M., and Kiyama, $\mathrm{H}$. (2003). Biphasic expression of activating transcription factor- 3 in neurons after cerebral infarction. Brain Res. Mol. Brain Res. 115, 147-156.

Pan, Y., Chen, H., Siu, F., and Kilberg, M. S. (2003). Amino acid deprivation and endoplasmic reticulum stress induce expression of multiple activating transcription factor-3 mRNA species that, when overexpressed in HepG2 cells, modulate transcription by the human asparagine synthetase promoter. J. Biol. Chem. 278 38402-38412.

Parsadanian, A., Pan, Y., Li, W. Myckatyn, T. M., and Brakefield, D. (2006). Astrocyte-derived transgene GDNF promotes complete and long-term survival of adult facial motoneurons following avulsion and differentially regulates the expression of transcription factors of AP-1 and ATF/CREB families. Exp. Neurol. 200, 26-37.

Pearson, A. G., Gray, C. W., Pearson, J. F., Greenwood, J. M., During, M. J., and Dragunow, M. (2003). ATF3 enhances c-Jun-mediated neurite sprouting. Brain Res. Mol. Brain Res. 120, 38-45.

Peddie, C. J., and Keast, J. R. (2011). Pelvic nerve injury causes a rapid decrease in expression of choline acetyltransferase and upregulation of c-Jun and ATF-3 in a distinct population of sacral preganglionic neurons. Front. Neurosci. 5:6. doi:10.3389/fnins.2011.00006

Penas, C., Font-Nieves, M., Fores, J., Petegnief, V., Planas, A., Navarro, X., and Casas, C. (2011). Autophagy, and BiP level decrease are early key events in retrograde degeneration of motoneurons. Cell Death Differ. 18, 1617-1627.

Perez, S., Vial, E., van, D. H., and Castellazzi, M. (2001). Transcription factor ATF3 partially transforms chick embryo fibroblasts by promoting growth factor-independent proliferation. Oncogene 20, 1135-1141.

Peters, C. M., Jimenez-Andrade, J. M., Jonas, B. M., Sevcik, M. A., Koewler, N. J., Ghilardi, J. R., Wong, G. Y., and Mantyh, P. W. (2007a) Intravenous paclitaxel administration in the rat induces a peripheral sensory neuropathy characterized by macrophage infiltration and injury to sensory neurons and their supporting cells. Exp. Neurol. 203, 42-54.

Peters, C. M., Jimenez-Andrade, J. M., Kuskowski, M. A., Ghilardi, J. R., and Mantyh, P. W. (2007b). An evolving cellular pathology occurs in dorsal root ganglia, peripheral nerve and spinal cord following intravenous administration of paclitaxel in the rat. Brain Res. 1168, 46-59.

Raineteau, O., Z'Graggen, W. J., Thallmair, M., and Schwab, M. E. (1999). Sprouting and regeneration after pyramidotomy and blockade of the myelin-associated neurite growth inhibitors NI 35/250 in adult rats. Eur. J. Neurosci. 11, 1486-1490.

Raivich, G., Bohatschek, M., Da, C. C., Iwata, O., Galiano, M., Hristova, M., Nateri, A. S., Makwana, M., RieraSans, L., Wolfer, D. P., Lipp, H. P., Aguzzi, A., Wagner, E. F., and Behrens, A. (2004). The AP-1 transcription factor c-Jun is required for efficient axonal regeneration. $\mathrm{Neu}$ ron 43, 57-67.

Ramon y Cajal, S. (1928). Degeneration and Regeneration in the Nervous System. London: Oxford University Press.

Rasschaert, J., Ladriere, L., Urbain, M. Dogusan, Z., Katabua, B., Sato, S., Akira, S., Gysemans, C., Mathieu, C., and Eizirik, D. L. (2005). Toll-like receptor 3 and STAT- 1 contribute to double-stranded RNA+ interferongamma-induced apoptosis in primary pancreatic beta-cells. J. Biol. Chem. 280, 33984-33991.

Richardson, P. M., McGuinness, U. M., and Aguayo, A. J. (1980). Axons from 
CNS neurons regenerate into PNS grafts. Nature 284, 264-265.

Roussel, L., Robins, S., Schachter, A., Berube, J., Hamid, Q., and Rousseau, S. (2011). Steroids and extracellular signal-regulated kinase $1 / 2$ activity suppress activating transcription factor 3 expression in patients with severe asthma. J. Allergy Clin. Immunol. 127, 1632-1634.

Saito, H., and Dahlin, L. B. (2008). Expression of ATF3 and axonal outgrowth are impaired after delayed nerve repair. BMC Neurosci. 9, 88. doi:10.1186/1471-2202-9-88

Salminen, A., Kauppinen, A., Suuronen, T., Kaarniranta, K., and Ojala, J. (2009). ER stress in Alzheimer's disease: a novel neuronal trigger for inflammation and Alzheimer's pathology. J. Neuroinflammation 6, 41.

Saul, K. E., Koke, J. R., and Garcia, D. M. (2010). Activating transcription factor 3 (ATF3) expression in the neural retina and optic nerve of zebrafish during optic nerve regeneration. Comp. Biochem. Physiol. A Mol. Integr. Physiol. 155, 172-182.

Segond von Banchet, G., Boettger, M. K., Fischer, N., Gajda, M., Brauer, R., and Schaible, H. G. (2009). Experimental arthritis causes tumor necrosis factor-alpha-dependent infiltration of macrophages into rat dorsal root ganglia which correlates with pain-related behavior. Pain 145, 151-159.

Seijffers, R., Allchorne, A. J., and Woolf, C. J. (2006). The transcription factor ATF- 3 promotes neurite outgrowth. Mol. Cell. Neurosci. 32, 143-154.

Seijffers, R., Mills, C. D., and Woolf, C. J. (2007). ATF3 increases the intrinsic growth state of DRG neurons to enhance peripheral nerve regeneration. J. Neurosci. 27, 7911-7920.

Shokouhi, B. N., Wong, B. Z., Siddiqui, S., Lieberman, A. R., Campbell, G., Tohyama, K., and Anderson, P. N. (2010). Microglial responses around intrinsic CNS neurons are correlated with axonal regeneration. BMC Neurosci. 11, 13. doi:10.1186/1471-2202-11-13

Smith, K. J., Kapoor, R., and Felts, P. A. (1999). Demyelination: the role of reactive oxygen and nitrogen species. Brain Pathol. 9, 69-92.

Smith, R. S. (1992). A comprehensive macrophage-T-lymphocyte theory of schizophrenia. Med. Hypotheses 39, 248-257.

Song, D. Y., Yang, Y. C., Shin, D. H., Sugama, S., Kim, Y. S., Lee, B. H., Joh, T. H., and Cho, B. P. (2008). Axotomy-induced dopaminergic neurodegeneration is accompanied with c-Jun phosphorylation and activation transcription factor 3 expression. Exp. Neurol. 209, 268-278.

Stimpson, C. D., Tetreault, N. A., Allman, J. M., Jacobs, B., Butti, C., Hof, P. R., and Sherwood, C. C. (2011). Biochemical specificity of von economo neurons in hominoids. Am. J. Hum. Biol. 23, 22-28.

Suganami, T., Yuan, X., Shimoda, Y., Uchio-Yamada, K., Nakagawa, N., Shirakawa, I., Usami, T., Tsukahara, T., Nakayama, K., Miyamoto, Y., Yasuda, K., Matsuda, J., Kamei, Y., Kitajima, S., and Ogawa, Y. (2009). Activating transcription factor 3 constitutes a negative feedback mechanism that attenuates saturated fatty acid/toll-like receptor 4 signaling and macrophage activation in obese adipose tissue. Circ. Res. 105, 25-32.

Takahashi, N., Kikuchi, S., Dai, Y., Kobayashi, K., Fukuoka, T., and Noguchi, K. (2003). Expression of auxiliary beta subunits of sodium channels in primary afferent neurons and the effect of nerve injury. Neuroreport 121, 441-450.

Takeda, M., Kato, H., Takamiya, A., Yoshida, A., and Kiyama, H. (2000). Injury-specific expression of activating transcription factor-3 in retinal ganglion cells and its colocalized expression with phosphorylated cJun. Invest. Ophthalmol. Vis. Sci. 41, 2412-2421.

Taketani, K., Kawauchi, J., TanakaOkamoto, M., Ishizaki, H., Tanaka, Y., Sakai, T., Miyoshi, J., Maehara, Y., and Kitajima, S. (2011). Key role of ATF3 in p53-dependent DR5 induction upon DNA damage of human colon cancer cells. Oncogene. doi: 10.1038/onc.2011.397. [Epub ahead of print].

Tamura, K., Hua, B., Adachi, S., Guney, I., Kawauchi, J., Morioka, M., Tamamori-Adachi, M., Tanaka, Y., Nakabeppu, Y., Sunamori, M., Sedivy, J. M., and Kitajima, S. (2005). Stress response gene ATF3 is a target of c-myc in serum-induced cell proliferation. EMBO J. 24, 2590-2601.

Tanaka, Y., Nakamura, A., Morioka, M. S., Inoue, S., Tamamori-Adachi, M., Yamada, K., Taketani, K., Kawauchi, J., Tanaka-Okamoto, M., Miyoshi, J., Tanaka, H., and Kitajima, S. (2011). Systems analysis of ATF3 in stress response and cancer reveals opposing effects on pro-apoptotic genes in p53 pathway. PLoS ONE 6, e26848. doi:10.1371/journal.pone.0026848

Thompson, M. R., Xu, D., and Williams, B. R. (2009). ATF3 transcription factor and its emerging roles in immunity and cancer. J. Mol. Med. (Berl.) 87, 1053-1060

Tsujino, H., Kondo, E., Fukuoka, T., Dai, Y., Tokunaga, A., Miki, K., Yonenobu, K., Ochi, T., and Noguchi, K. (2000). Activating transcription factor 3 (ATF3) induction by axotomy in sensory and motoneurons: a novel neuronal marker of nerve injury. Mol. Cell. Neurosci. 15 170-182.

Tsuzuki, K., Kondo, E., Fukuoka, T., Yi, D., Tsujino, H., Sakagami, M., and Noguchi, K. (2001). Differential regulation of $\mathrm{P} 2 \mathrm{X}(3)$ mRNA expression by peripheral nerve injury in intact and injured neurons in the rat sensory ganglia. Pain 91, 351-360.

Tsuzuki, K., Noguchi, K., Mohri, D., Yasuno, H., Umemoto, M., Shimobayashi, C., Fukazawa, K., and Sakagami, M. (2002). Expression of activating transcription factor 3 and growth-associated protein 43 in the rat geniculate ganglion neurons after chorda tympani injury. Acta Otolaryngol. 122, 161-167.

Tucker, B. A., and Mearow, K. M. (2008). Peripheral sensory axon growth: from receptor binding to cellular signaling. Can. J. Neurol. Sci. 35 , 551-566.

Vogelezang, M. G., Scherer, S. S., Fawcett, J. W., and ffrench-Constant, C. (1999). Regulation of fibronectin alternative splicing during peripheral nerve repair. J. Neurosci. Res. 56 , 323-333.

Vos, B. P., Strassman, A. M., and Maciewicz, R. J. (1994). Behavioral evidence of trigeminal neuropathic pain following chronic constriction injury to the rat's infraorbital nerve. J. Neurosci. 14, 2708-2723.

Wang, J., Cao, Y., and Steiner, D. F. (2003). Regulation of proglucagon transcription by activated transcription factor (ATF) 3 and a novel isoform, ATF3b, through the cAMPresponse element/ATF site of the proglucagon gene promoter. J. Biol. Chem. 278, 32899-32904.

Weidenfeld-Baranboim, K., Hasin, T., Darlyuk, I., Heinrich, R., Elhanani, O., Pan, J., Yokoyama, K. K., and Aronheim, A. (2009). The ubiquitously expressed bZIP inhibitor, JDP2, suppresses the transcription of its homologue immediate early gene counterpart, ATF3. Nucleic Acids Res. 37, 2194-2203.

Weigelt, K., Carvalho, L. A., Drexhage, R. C., Wijkhuijs, A., Wit, H. D., van Beveren, N. J., Birkenhager, T. K., Bergink, V., and Drexhage, H. A. (2011). TREM-1 and DAP12 expression in monocytes of patients with severe psychiatric disorders. EGR3, ATF3 and PU.1 as important transcription factors. Brain Behav. Immun. 25, 1162-1169.

Whitmore, M. M., Iparraguirre, A., Kubelka, L., Weninger, W., Hai, T., and Williams, B. R. (2007). Negative regulation of TLR-signaling pathways by activating transcription factor-3. $J$. Immunol. 179, 3622-3630.

Williams, K. L., Rahimtula, M., and Mearow, K. M. (2006). Heat shock protein 27 is involved in neurite extension and branching of dorsal root ganglion neurons in vitro. J. Neurosci. Res. 84, 716-723.

Wolfgang, C. D., Chen, B. P., Martindale, J. L., Holbrook, N. J., and Hai, T. (1997). gadd153/Chop10, a potential target gene of the transcriptional repressor ATF3. Mol. Cell. Biol. 17, 6700-6707.

Wolfgang, C. D., Liang, G., Okamoto, Y., Allen, A. E., and Hai, T. (2000). Transcriptional autorepression of the stress-inducible gene ATF3. J. Biol. Chem. 275, 16865-16870.

Wong, Y. C., Zhang, X. M., Ling, M. T., and Wang, X. H. (2008). Inactivation of ID-1 gene induces sensitivity of prostate cancer cells to chemotherapeutic drugs. Adv. Exp. Med. Biol. $617,565-572$

Yamanaka, H., Obata, K., Fukuoka, T., Dai, Y., Kobayashi, K., Tokunaga, A., and Noguchi, K. (2005). Induction of plasminogen activator inhibitor-1 and -2 in dorsal root ganglion neurons after peripheral nerve injury. Neuroreport 132, 183-191.

Yan, C., Lu, D., Hai, T., and Boyd, D. D. (2005). Activating transcription factor 3 , a stress sensor, activates $\mathrm{p} 53$ by blocking its ubiquitination. $E M B O J$. 24, 2425-2435.

Yano, K., Kawasaki, K., Hattori, T., Tawara, S., Toshima, Y., Ikegaki, I., Sasaki, Y., Satoh, S., Asano, T., and Seto, M. (2008). Demonstration of elevation and localization of Rho-kinase activity in the brain of a rat model of cerebral infarction. Eur. J. Pharmacol. 594, 77-83.

Yin, T., Sandhu, G., Wolfgang, C. D., Burrier, A., Webb, R. L., Rigel, D. F., Hai, T., and Whelan, J. (1997). Tissue-specific pattern of stress kinase activation in ischemic/reperfused heart and kidney. J. Biol. Chem. 272, 19943-19950.

Yin, X., Dewille, J. W., and Hai, T. (2008). A potential dichotomous role of ATF3, an adaptive-response gene, in cancer development. Oncogene 27, 2118-2127. 
Yin, X., Wolford, C. C., Chang, Y. S., McConoughey, S. J., Ramsey, S. A., Aderem, A., and Hai, T. (2010). ATF3, an adaptive-response gene, enhances TGF $\{$ beta $\}$ signaling and cancer-initiating cell features in breast cancer cells. J. Cell. Sci. 123, 3558-3565.

Yin, Y., Cui, Q., Li, Y., Irwin, N., Fischer, D., Harvey, A. R., and Benowitz, L. I. (2003). Macrophage-derived factors stimulate optic nerve regeneration. J. Neurosci. 23, 2284-2293.

Zeng, B. Y., Anderson, P. N., Campbell, G., and Lieberman, A. R. (1994). Regenerative and other responses to injury in the retinal stump of the optic nerve in adult albino rats: transection of the intraorbital optic nerve. J. Anat. 185, 643-661.

Zhang, S. J., Buchthal, B., Lau, D., Hayer, S., Dick, O., Schwaninger, M., Veltkamp, R., Zou, M., Weiss, U., and Bading, H. (2011). A signaling cascade of nuclear calcium-CREB-ATF3 activated by synaptic NMDA receptors defines a gene repression module that protects against extrasynaptic NMDA receptor-induced neuronal cell death and ischemic brain damage. $J$. Neurosci. 31, 4978-4990.

Zigmond, R. E., and Vaccariello, S. A. (2007). Activating transcription factor 3 immunoreactivity identifies small populations of axotomized neurons in rat cervical sympathetic ganglia after transection of the preganglionic cervical sympathetic trunk. Brain Res. 1159, 119-123.

Zmuda, E. J., Viapiano, M., Grey, S. T., Hadley, G., Garcia-Ocana, A., and Hai, T. (2010). Deficiency of ATF3, an adaptive-response gene, protects islets and ameliorates inflammation in a syngeneic mouse transplantation model. Diabetologia 53, 1438-1450.

Conflict of Interest Statement: The authors declare that the research was conducted in the absence of any commercial or financial relationships that could be construed as a potential conflict of interest.

Received: 06 December 2011; accepted: 20 January 2012; published online: 14 February 2012

Citation: Hunt D, Raivich G and Anderson PN (2012) Activating transcription factor 3 and the nervous system. Front. Mol. Neurosci. 5:7. doi: 10.3389/fnmol.2012.00007

Copyright (๑) 2012 Hunt, Raivich and Anderson. This is an open-access article distributed under the terms of the Creative Commons Attribution Non Commercial License, which permits noncommercial use, distribution, and reproduction in other forums, provided the original authors and source are credited. 